NBER WORKING PAPER SERIES

\title{
GOOD BYE LENIN (OR NOT?): THE EFFECT OF COMMUNISM ON PEOPLE'S PREFERENCES
}

\author{
Alberto Alesina \\ Nicola Fuchs-Schündeln \\ Working Paper 11700 \\ http://www.nber.org/papers/w11700 \\ NATIONAL BUREAU OF ECONOMIC RESEARCH \\ 1050 Massachusetts Avenue \\ Cambridge, MA 02138 \\ October 2005
}

We thank Matthias Schündeln and Andrei Shleifer for conversations, Susanto Basu and participants in seminars at Boston College, Harvard University, and the Max Planck Institute for Research on Collective Goods, Bonn, for comments, and Antonia Attanassova, Filipe Campante, and Francesco Trebbi for excellent research assistantship. Alesina gratefully acknowledges financial support from the NSF with a grant through the NBER. Fuchs-Schündeln thanks the Institute for the Study of Labor (IZA) for its hospitality. The views expressed herein are those of the author(s) and do not necessarily reflect the views of the National Bureau of Economic Research.

(C)2005 by Alberto Alesina and Nicola Fuchs-Schündeln. All rights reserved. Short sections of text, not to exceed two paragraphs, may be quoted without explicit permission provided that full credit, including (C) notice, is given to the source. 
Good bye Lenin (or not?): The Effect of Communism on People's Preferences

Alberto Alesina and Nicola Fuchs-Schündeln

NBER Working Paper No. 11700

October 2005

JEL No. H3, E6

\begin{abstract}
Preferences for redistribution, as well as the generosities of welfare states, differ significantly across countries. In this paper, we test whether there exists a feedback process of the economic regime on individual preferences. We exploit the "experiment" of German separation and reunification to establish exogeneity of the economic system. From 1945 to 1990, East Germans lived under a Communist regime with heavy state intervention and extensive redistribution. We find that, after German reunification, East Germans are more in favor of redistribution and state intervention than West Germans, even after controlling for economic incentives. This effect is especially strong for older cohorts, who lived under Communism for a longer time period. We further find that East Germans' preferences converge towards those of West Germans. We calculate that it will take one to two generations for preferences to converge completely.
\end{abstract}
Alberto Alesina
Department of Economics
210 Littauer Center
Harvard University
Cambridge, MA 02138
and NBER
aalesina@harvard.edu
Nicholas Fuchs Schündeln
Department of Economics
212 Littauer Center
Harvard University
Cambridge, MA 02138
nfuchs@harvard.edu 


\section{Introduction}

Are individual policy preferences exogenous or are they endogenous to political regimes? We focus in particular on tastes for redistribution and redistributive policies which in fact differ significantly across countries. ${ }^{1}$ Are the regimes different solely because of different initial preferences for redistribution in the populations? Or is there a feedback effect from the regime on preferences? Is it possible that living under a specific system leads to adaptation of preferences? ${ }^{2}$

In order to analyze these questions empirically, one needs an exogenous shock to the regime; post war Germany offers an opportunity to analyze the effect of Communism on people's preferences. From 1945 to 1990, Germany was split into two parts for reasons that had nothing to do with Germans' desire for separation, or diversity of tastes between East Germans and West Germans: the division of Germany into two parts was exogenous with respect to underlying individual preferences. Since the political and economic system has been the same in the eastern and western parts of Germany since reunification in 1990, and was the same before 1945, West Germans constitute a meaningful control group for East Germans. Therefore, comparing the differences in attitudes and preferences of Germans after the reunification can give us a clue about the effects of living for 45 years under a Communist regime on attitudes, beliefs and political preferences.

We are especially interested in measuring how 45 years of Communism affected individuals' thinking toward market capitalism and the role of the state in providing insurance and redistribution from the rich to the poor. If political regimes had no effect on individual preferences, one should not observe any systematic differences between East and West Germans after reunification. If Communism had an effect, in

\footnotetext{
${ }^{1}$ For instance, the difference between Europe and the US has been discussed recently by Alesina and Glaeser (2004).

${ }^{2}$ Several recent theoretical papers have shown that there is scope for multiple equilibria and selffulfilling beliefs in redistributive policies (see e.g. Piketty 1995, Alesina and Angeletos 2005, and Benabou and Tirole 2005).
} 
principle one could think of two possible reactions to 45 years of Communist dictatorship. One is that people turn strongly against the "state" and switch to preferences in the opposite direction, namely in favor of libertarian free markets, as a reaction to an all intrusive state. The opposite hypothesis is that 45 years of heavy state intervention and indoctrination instill in people the view that the state is essential for individual well being. As we shall see, we quickly and soundly reject the first hypothesis in favor of the second. In fact, we find that the effects of Communism are large and long lasting. It will take about one to two generations for former East and West Germans to look alike in terms of preferences and attitudes about fundamental questions regarding the role of the government in society.

We are interested in the effect of Communism on intrinsic preferences. This effect could arise because of Marxist Leninist indoctrination, state control over school, press, or state television, etc. Also, simply becoming accustomed to an all encompassing state may make people think of it as necessary and preferable despite the suffocating aspects of the East German regime. Beside this effect, there exists a purely economic effect, which arises because Communism has made former East Germany relatively poorer than former West Germany. Since the poor disproportionately benefit from government redistribution, they favor it. We find evidence of both types of effects.

We also investigate why former East Germans are more likely to favor state intervention (beside the economic effect). One reason is that they are simply used to it. Another reason is that East Germans believe much more so than West Germans that social conditions, rather than individual effort and initiative, determine individual fortunes; this belief is of course a basic tenet of the communist ideology. The more one thinks that it is society's "fault" if one is poor, unemployed or sick, the more one is in favor of public intervention. We find evidence for both effects.

Last, we analyze whether preferences of East Germans converge towards those of West Germans, given that they now live under the same regime West Germans have experienced since 1945. We calculate that, under the strict assumption of linearity, it 
will take about 20 to 40 years to make the difference between East and West Germans disappear almost completely, due to the combination of two forces. One is the dying of the elderly and the coming of age of individuals born after reunification; the other is the actual change of preferences of any given individual. We estimate the first effect to account for about one third of the convergence effect and the second one to account for the remaining two thirds of the convergence.

An implication of all of the above is that Germany in 1990 has been subject to a major political shock, perhaps with deeper and longer lasting consequences than the widely studied economic shock associated with the reunification. ${ }^{3}$

The question of preferences for redistribution and different visions about the welfare state has recently received much attention. Alesina and Glaeser (2004) discuss the origin of different beliefs and preferences in the US and Continental Western Europe, and in fact place a lot of weight on the influence of Marxist ideology on the preference for redistribution in Europe versus the US. Alesina and La Ferrara (2005) and Fong (2003) investigate the connection between views about social mobility and preferences for redistribution using US data. Ravallion and Lokshin (2000) consider Russian data. In general, this literature finds that the more individuals perceive that there is social mobility the less favorable they are to government redistribution.

The paper most closely related to ours is Corneo (2001). Building on Corneo and Grüner (2002), he studies empirically what motivates individuals to favor redistribution, from purely individual to altruistic motives. In examining this issue, Corneo (2001) compares preferences in the US, West Germany and East Germany. One of his results is that East Germans are more favorable to redistribution than West Germans, who, in turn, are more favorable to it than Americans. More generally, in a comparison of six Eastern European and six Western countries, Corneo and Grüner (2002) find large country fixed effects for Eastern European countries; i.e. they find

\footnotetext{
${ }^{3}$ Giavazzi and McMahon (2005) have recently pointed out how the German reform process in fact is lacking political support from the people.
} 
that Eastern Europeans have stronger preferences for redistribution than individuals from Western countries. Corneo (2001) as well as Corneo and Grüner (2002) use data from the 1992 round of the International Social Survey Programme. We can expand on their analyses since we use a panel data set that includes many more individual controls. By using different waves of our data, we can discuss more precisely timing issues and speed of convergence of preferences. By focusing on Germany, we can distinguish more clearly the role of Communism in shaping preferences from other potential reasons why Eastern Europeans might favor redistribution. That is, it could be that preferences in Eastern Europe are different because of different cultures, histories etc. even before the advent of Communism. Moreover, a more uncertain environment and absence of insurance markets could induce Eastern Europeans to favor redistribution. ${ }^{4}$ Last, we analyze preferences a decade after the transition started. At this point, it is harder to argue that uncertainty about future economic conditions was larger in East Germany than in the West. Ockenfels and Weimann (1999) conduct public goods and solidarity experiments with East and West German subjects and detect significantly different behavior between both groups, which they attribute to the effects of Communism in East Germany versus Capitalism in the West on norms.

The paper is organized as follows. In Section 2 we describe the institutional background, and the data. In Section 3 we present our basic results concerning preferences for state intervention in social policy. Section 4 investigates related attitudes about the role of individual responsibility versus social conditions in determining success in life. These attitudes can potentially explain differences in preferences regarding the welfare state. The last section concludes.

\footnotetext{
${ }^{4}$ These two reasons (in addition to language issues) make the interpretation of results from crosscountry studies especially hard. Other cross-country studies that analyze the legacy of Communism on attitudes towards free markets and labor markets are Shiller, Boycko, and Korobov (1991, 1992), and Blanchflower and Freeman (1997). The effect of Communism on religious beliefs is studied by McCleary and Barro (2003) and Barro and McCleary (2005). They find that Communism has significant and potentially long lasting negative effects on individual religiosity and on the adoption of state religions.
} 


\section{Institutional background and data}

\subsection{Institutional background}

\subsubsection{German separation and reunification}

Germany as a country was created in 1871 as a result of the political unification of 18 independent political units of various size, the largest and most powerful being Prussia. Germany remained a single country until the end of the Second World War when, as a losing power, it was split amongst the winning Allies. East Germany was under the sphere of influence of the Soviets, while the West was occupied by the US, France, and the UK. The borders between East and West Germany were the result of bargaining between the Allies and the position of the occupying forces at the end of hostilities. In 1949, both the Federal Republic of Germany (FRG) and the German Democratic Republic (GDR) were officially founded. The East German regime developed as one of the most rigid of the former Communist regimes. Income inequality in the GDR was low: in 1988, the average net income of individuals with a university degree was only $15 \%$ higher than that of blue collar workers, compared to $70 \%$ in the FRG. Also, intersectoral differences in net incomes were minimal, on average amounting only to 150 Mark per month with an average monthly income of around 1100 Mark in 1988 (Stephan and Wiedemann, 1990, Schäfgen, 1998). Reunification occurred rather quickly and abruptly in October 1990, 11 months after the fall of the Berlin Wall in November 1989. East Germany became part of the Federal Republic of Germany, and the economic and political system of the West was transferred to the East.

\subsubsection{Germany before 1945}

One important identifying assumption of our analysis is that East and West Germany were indistinguishable until the exogenously imposed separation in 1945. Because of this, if we observe differences in attitudes of East and West Germans after reunifi- 
cation, we can attribute them to 45 years of Communism. How reasonable is the assumption that East and West Germans were indistinguishable in terms of their attitudes before 1945? Table A1 shows average per capita income levels of different German regions, as well as subregions of Prussia, in 1928, 1932, and 1936. We mark a region by $\mathrm{E}$ or $\mathrm{W}$, depending on whether it mainly belonged to the GDR or FRG between 1949 and 1990. Unmarked regions do not belong to Germany after $1945 .^{5}$ As the table shows, the level of income per capita in pre-World War II Germany does not show any systematic difference between East and West; in fact, on average they are almost identical. ${ }^{6}$ Moreover, destruction during World War II was major and universal in both the later FRG and GDR.

However, income per capita aside, there might have been differences in attitudes before 1945. One possible issue is that Prussians might have had a more militarist "state-centric" view about the state than other Germans. Note however that part of former Prussia belonged to the FRG and part to the GDR between 1949 and 1990, and not all regions of the later GDR belonged to Prussia (see Table A1). We address the issue of Prussia explicitly in section 3.

The period of the "Weimar Republic" (1918 to 1933) enhanced conformity between the German regions. Yet, already before that at the turn of the last century, the later East and West Germany were quite similar along many economic dimensions, e.g. with regard to the percentage of the population working in industry, agriculture, or commerce (Statistisches Jahrbuch für das Deutsche Reich, 1898, pp. 224-233). ${ }^{7}$ Moreover, in the elections of 1898, around the same number of constituencies in the

\footnotetext{
${ }^{5}$ Note that some regions transcend the borders established after World War II, in which case we assign the region to East, West or outside Germany depending on its largest share.

${ }^{6}$ The non-population weighted average income in later East regions amounted to 1,203 Mark in 1928, 877 Mark in 1932, and 1,169 Mark in 1936, while the corresponding incomes for the later West regions are 1,203, 913, and 1,200 Mark.

${ }^{7}$ The perception that the territory of the GDR was different (e.g. more agricultural) than the West before 1945 seems to be caused by the fact that the far Eastern part of Germany in the borders before 1945 was indeed much more rural. Yet, this refers to the regions that after 1945 belonged to Poland, Russia, and Czechoslovakia, not to the GDR.
} 
later East and West Germany voted primarily in favor of the Social Democrats. In the

West, the largest party was the Zentrum party, which was more in support of state intervention than the Conservatives, which was the most prominent party beside the Social Democrats in the East (Statistisches Jahrbuch für das Deutsche Reich, 1899, pp. 246-247). Hence, it seems that, if anything, the West was at that time more in favor of state intervention than the East.

\subsubsection{East-West migration between 1945 and 1989}

From a peak population of 19.1 million people living in 1947 in the Soviet zone that officially became the GDR in 1949, around 3 million people emigrated into the FRG before the Berlin Wall was built in August 1961 (Rytlewski and Opp de Hipt, 1987, Storbeck, 1963, Heidemeyer, 1994). ${ }^{8}$ From August 1961 to December 1988, only slightly more than 600,000 people emigrated from East to West (Schumann et al., 1996). The large number of East-West migrants before 1961 is in contrast to only around 30,000 people per year emigrating from West to East in the 1950s, and almost no West-East emigration after 1961 (Münz and Ulrich, 1997). Migration poses a challenge to our identification, since it raises the possibility of self-selection: if the distributions of preferences for state intervention were identical in East and West before 1945, but migration after 1945 was largely driven by these preferences, then this could explain why we would observe stronger preferences for state intervention in the East in the 1990s.

The sociological literature acknowledges six main reasons for East-West migration, namely fleeing from the Soviet army (Hiergebliebene), returning after having been displaced during the war, migration to the West via the East of emigrants from parts of the former German Reich not belonging to Germany any more after 1945, political reasons, migration of individuals who suffered from expropriation and other economic discrimination, and general economic reasons. While extensive survey evidence on

\footnotetext{
${ }^{8}$ The reported numbers are estimates based on different data sources. Data of migration flows before 1949 are especially unreliable.
} 
the reasons of migration does not exist, it is widely believed that family reunions and the economic prosperity of the West were the two main reasons for migration (see e.g. Heidemeyer, 1994, and Storbeck, 1963). Although surely preferences for state intervention played a role for migration, it is not clear that this motive is strong enough to explain any observed differences in preferences between East and West Germans after reunification. Moreover, the number of emigrants is probably not large enough to explain large differences in preferences afterwards. Last, if stronger preferences for state intervention in the East than in the West would be caused exclusively by self-selection, then this difference should be persistent over time after reunification; in fact it is not, as we shall see.

\subsection{Data}

The German Socioeconomic Panel (GSOEP) is an annual household panel, started in West Germany in 1984. From 1990 on, it also covers the territory of the former German Democratic Republic. We use the original sample established in 1984, and the sub-sample covering the territory of the former GDR started in 1990. The original West German sample leaves us with around 11,400 year-person observations, while the East German sample covers around 7,000 year-person observations for 1997 and $2002 .^{9}$

In 1997 and 2002, respondents were asked questions concerning their preferences for the role of the state in different areas of social security. The question reads: "At present, a multitude of social services are provided not only by the state but also by private free market enterprises, organizations, associations, or private citizens. What is your opinion on this? Who should be responsible for the following areas?". We use the answers to all areas that concern financial security, namely "financial security in case of unemployment", "financial security in case of illness", "financial security of families", "financial security for old-age", and "financial security for persons needing

\footnotetext{
${ }^{9}$ The numbers of observation vary slightly with the dependent variable.
} 
care". ${ }^{10}$ The answers are given on a scale of 1 to 5 , which correspond to "only the state", "mostly the state", "state and private forces", "mostly private forces", and "only private forces". We group the first 2 answer categories together to represent individuals with preference for an active role of the state in providing for its citizens, and group the last 3 answer categories together to represent individuals with preferences for private forces. Hence, we create 5 new dummy variables which take on the value of 1 if the respondent answered "only the state" or "mostly the state" for the respective area, and 0 otherwise. This is mainly done to ease the interpretation of the coefficients. As a robustness check, we run ordered probit regressions on the original variables, and the results do not change significantly. ${ }^{11}$ Table A2 reports the summary statistics of our newly created variables. ${ }^{12}$

Our explanatory variable of main interest is an East dummy that takes on the value of 1 if the respondent lived in East Germany before reunification, regardless of the current place of residence. Hence, this dummy captures people who lived under Communism before 1990. The baseline controls include age, gender, marital status, labor force status, education, and occupation of the respondent, the number of children and the number of adults in the household, as well as the annual household income. All monetary variables are in 2002 DM.

We analyze two additional questions that capture the belief of the respondent regarding important driving forces of success in life. In 1996 and 1999, GSOEP asked the following question: "The following statements express varying attitudes towards life and the future. Please state whether you totally agree, agree slightly, disagree slightly, or totally disagree", followed by several statements that differ between 1996 and 1999. The first statement we use refers to the role of luck in life. We create a dummy variable "luck" that takes on the value of 1 if the respondent agreed totally or

\footnotetext{
${ }^{10}$ The questions of interest hence capture different areas of state intervention associated with redistribution and insurance.

${ }^{11}$ The basic results using ordered probits are shown in Table A5. All other results are available from the authors upon request.

${ }^{12}$ Table A3 reports summary statistics for the independent variables.
} 
slightly with the statements "No one can escape their fate, everything in life happens as it must happen" in 1996 and "What one achieves in life is mainly a question of luck or fate" in 1999. ${ }^{13}$ Similarly, the dummy variable "social conditions" takes on the value 1 if the respondent agreed totally or slightly with the statement "The possibilities in my life are determined by the social conditions". ${ }^{14}$ The answers to these questions are also summarized in Table A2.

Table A4 shows income per capita and unemployment rates in German states (Bundesländer) in 1997 and 2002, as well as transfers per capita that each state receives from other states and the federal government in line with the German financial transfer system (see the appendix for an overview of the German transfer system). Average income per capita in the East is around $80 \%$ of the average West income, and the unemployment rate is roughly twice as large. As we discussed above, before WWII per capita income levels in East and West Germany were virtually identical. The 20 percent difference in per capita income after reunification can be interpreted as the effect of 45 years of different economic and political experiences on economic development. The lower income levels as well as the higher unemployment rates lead to the fact that all eastern German states are net recipients of transfers. Among the western German states, five are net givers, while four are net recipients. Yet, with the exception of the small state of Bremen, the average transfer received is much larger in the East than among the net recipients in the West.

\section{Basic results}

Table 1 reports results from our basic specification, in which we include as explanatory variables many individual characteristics and our variable of interest, being from the East. As we discussed above, the left hand side variable is defined as a $0 / 1$ variable with 1 meaning support for an active state role. We also rerun all these regressions

\footnotetext{
${ }^{13}$ We take the average of both questions to alleviate potential measurement error.

${ }^{14}$ This question was asked in 1999. There is no equivalent statement in 1996.
} 
using the entire five point scale, and the results are consistent. Table A5 in the appendix is the same as Table 1, but the left hand side variable has the five point scale, and an ordered probit estimation is conducted. In the main text, we report the results from probit regressions for ease of interpretation. ${ }^{15}$

The first three explanatory variables are the critical ones; and for all five questions they behave similarly. Consider column 1, which concerns unemployment. An East German is significantly more likely to have preferences for state provision of financial security for the unemployed than a West German. Over time, however, the East Germans are becoming less pro state, since the interaction between being from the East and the 2002 dummy (the third variable) is negative and statistically significant. The dummy variable of being an East German and the interaction of that with 2002 have similar coefficients on all questions. The coefficients on the East indicator variable vary from 0.37 to 0.43 , and are hence rather uniform. The interaction of East with 2002 (a rough measure of convergence) varies from -0.06 to -0.18 . The economic meaning of these numbers is as follows. Being from the East increases the probability of favoring state intervention by between 14.5 and 17 percentage points in 1997, compared to being from the West. Between 1997 and 2002, the probability of favoring state intervention for an East German declines by between 2.3 and 6.9 percentage points. Given that these questions are reported at a 5 year interval (1997 and 2002), a very rough measure of convergence would imply full uniformity of views from a minimum of about 11 years (column 5) to a maximum of 35 years in column 3. Given that the first survey was taken 7 years after reunification, the complete cycle of convergence (assuming that it is linear) would be between roughly 20 and 40 years, depending on the question; roughly one to two generations. ${ }^{16}$

\footnotetext{
${ }^{15}$ The coefficients reported in the tables are the total coefficients. We report the corresponding marginal coefficients in the text when we are interpreting the size of the coefficients. The marginal coefficients of interaction variables are calculated as the cross partial derivatives (Ai and Norton, 2003). The marginal effect on $y$ of a dummy variable $x$ has been calculated as $E[y \mid x=1]-E[y \mid x=0]$.

${ }^{16}$ Our results are based on unweighted observations. If we use the sample weights provided by GSOEP, the results are very similar. The only difference worth mentioning is that the convergence results become on average weaker, indicating an even longer process of convergence. However, when
} 
The dummy for 2002 captures the change in preferences of a West German between 1997 and 2002. Note that it is significantly positive, indicating that westerners are becoming more pro government, for 3 of the 5 regressions. In none of the five regressions is there significant evidence that West Germans are becoming less pro government.

The estimates on individual controls yield reasonable results. Men are generally less pro government (although not consistently on all questions). Larger families, both in terms of number of children and number of adults, are more favorable to government intervention, not surprisingly, since they get more benefits. Interestingly, civil servants have weaker preferences than others for government intervention for the unemployed, probably because they have very high job security. On the contrary, those who are unemployed strongly prefer government intervention for unemployed. Income enters negatively and is statistically significant on all questions; the wealthy benefit less from government intervention and pay more for it. Similarly, college educated individuals favor private forces over the state. Self employed are less pro government either because they benefit less from redistribution, or because being self employed is correlated with a more individualistic vision of the world and/or with less risk aversion (Fuchs-Schündeln and Schündeln, 2005). ${ }^{17}$ All these variables are always included as controls in all the regressions, and the coefficients are quite stable. From now on, we do not report them to avoid cluttering the tables.

The data set also includes two variables which proxy for wealth. One is the amount of interest and dividend income obtained by the household of the respondent; the second is whether or not the household owns the house it lives in. The inclusion of these controls might be important, since preferences regarding insurance provided by the state might be influenced by the possibilities to self-insure through private

we include wealth variables as controls (as described at the end of this section), the convergence results are again very similar to the unweighted results.

${ }^{17}$ All these results on individual controls are qualitatively similar to those obtained for the US by Alesina and La Ferrara (2005). 
wealth holdings. When we add these variables in the regressions, the results on the East-West differences remain however almost unchanged. The coefficients on the two wealth variables have the expected signs and are statistically significant. These results are reported in Table 2. We do not include these two wealth controls in our basic regressions because of data availability. After the inclusion of these variables, we lose around 2,200 observations because of non respondence. We checked all our results including these two variables, in addition to those of Table 1, and the results are robust. ${ }^{18}$

To make sure that we capture the effect of having lived in the East, and not the effect of being "Prussian", we also include a "Prussia-dummy" as a control into our regressions. This dummy takes on the value of 1 if in the spring of 1990 the individual lived in a region that historically belonged to Prussia. ${ }^{19}$ The definition of a region here is the Raumordnungsregion of residence. There are 97 Raumordnungsregionen in Germany in 1990, of which 23 are in the East, and 42 have assigned the value of 1 for the "Prussia-dummy". ${ }^{20}$ The estimates of the "Prussia-dummy" are sometimes positive and sometimes negative, but never significant. ${ }^{21}$ Moreover, its inclusion does not change any of the results. Hence, we conclude that we do not capture the effect of being "Prussian", but rather the effect of having lived under Communism.

\subsection{Age and cohort effects}

Let us now consider more closely the effects of the number of years under Communism on individual preferences. Table 3 shows some striking results. ${ }^{22}$ Consider column 1. The variable "age" corresponds to the age of the respondent. The East indicator

\footnotetext{
${ }^{18}$ These results are available upon request.

${ }^{19}$ We use Prussia in its borders from 1871 to 1914.

${ }^{20} \mathrm{We}$ assign the value of 1 to a Raumordnungsregion, if the major part of its territory belonged to Prussia. As explained in section 2.1.2, not all Raumordnungsregionen of the East belonged to Prussia, and some Raumordnungsregionen of the West did belong to Prussia.

${ }^{21}$ Results are available from the authors upon request.

${ }^{22}$ In the regressions of this table we do not include the variables age squared and age cubed to facilitate the comparison of the age effect.
} 
variable interacted with age is positive, meaning that older former East Germans are more favorable to state intervention. Note how age not interacted with East is negative, meaning that West Germans are becoming less pro government as they become older, the same result found for the US by Alesina and La Ferrara (2005). The effect of age on preferences is exactly opposite in East and West. The same pattern applies to all other questions. The obvious interpretation of these strikingly different age patterns between East Germans and West Germans is that while age tends to make individuals less pro government in West Germany, this effect is more than compensated by the fact that elderly East Germans have lived longer under Communism.

Table 4 pushes this age analysis further by looking at five different groups of birth cohort. The five groups are defined as follows: born after 1975, born between 1961 and 1975, born between 1946 and 1960, born between 1931 and 1945, and born on or before 1930. Note that the youngest group did only spend their childhood and early adolescence under Communism; this is the omitted group in the regressions. This table shows that the older are progressively more pro government than the younger in the East, a pattern not observed in the West, in which in fact the older tend to be less pro government than the younger. Interestingly, for some of the questions the old rather than the oldest group in the East shows the maximum support of government. Note that the individuals born on or before 1930 lived a significant part of their life before Communism was introduced.

The quantitative implications of the birth cohort effects are large. Figure 1 represents the results from Table 4 in a different way; it shows by how many percentage points an East German of a certain cohort group is more likely to favor state intervention than a West German of the same cohort group. While an East German from the youngest group is only between 3 (column 4) and 11 (column 1) percentage points more likely to be in favor of government redistribution than a West German of the same group, an East German born on or before 1930 is between 21 percentage points 
(column 1) and 49 percentage points (column 4) more likely than a West German of the same cohort group to believe in government redistribution.

\subsection{Decomposition of change over time}

Given that we observe that older East Germans are more in favor of redistribution than younger ones, the question arises whether the observed decline in East Germans' preferences for redistribution between 1997 and 2002 is simply a result of a shift in the cohort composition, or whether it is caused by changing personal preferences of East Germans. Even if personal preferences were constant over time, we would expect that East German preferences converge on average to West German preferences as older East Germans die and East Germany becomes populated by relatively younger households who have spent less time of their life under Communism.

To investigate the relative importance of both effects, in Table 5 we report results from the baseline regressions in which we include only individuals who answer the relevant questions in both 1997 and 2002. ${ }^{23}$ Hence, all changes in preferences between 1997 and 2002 are due to changing personal preferences, and not due to changes in the cohort composition. The interaction effect between East and year 2002 is still negative in all 5 regressions, and significant in all cases except financial security of families (column 3). However, the East time effect is now on average substantially smaller than in the baseline regressions; in absolute terms, it is increasing by $1 \%$ in column 1, up to declining by $63 \%$ in column 3 . On average, the East time effect is $35 \%$ smaller than the effect reported in the baseline results in Table 1 . Hence, we conclude that around two thirds of the convergence arises from actual convergence of preferences, while around one third arises from changes in the cohort composition. ${ }^{24}$ The fact that we find significant actual convergence of preferences points against the

\footnotetext{
${ }^{23}$ Note that we use an unbalanced sample for the general results.

${ }^{24}$ The number of observations drops by around $24 \%$ if we restrict the sample to those individuals who answer in both 1997 and 2002. Note that the cohort results from Table 4 are consistent with the conclusion from this section that one third of the convergence over time can be attributed to the shifting cohort composition.
} 
hypothesis that the East effect is only due to self-selection of individuals into the West before 1961, and that individual preferences are stable over time.

\subsection{The effect of Communism: Poverty or preferences?}

\subsubsection{Individual economic effects}

The poor tend to favor government intervention more than the rich. In our regressions, we always include the logarithmic household income of the respondent as a control, and the coefficient on this variable is always negative and statistically significant. Hence, we are measuring the effects of having been in the East controlling for the fact that the respondent's income might be lower precisely because he or she lived in the East. In order to allow for further non-linearities between income and preferences, we also include a fourth order polynomial of household income instead of the logarithm of household income, and our estimates remain virtually unchanged. ${ }^{25}$

In order to capture the extent to which a household currently benefits from redistribution, in Table 6 we split household income up by its sources and include the logarithms of different income components as explanatory variables. ${ }^{26}$ The first eight sources of income reported in Table 6 are based on government support (e.g. pension income, unemployment benefit, maternity benefit), while the last four listed sources of income are private (e.g. wage income, and income from self-employment). One would expect a negative effect of income on preferences for state intervention mostly for this last group. Indeed, the coefficients for this group are almost always negative, and often significant. This is especially true for wage income and income from self-employment. On the other hand, the coefficients on government income sources are mostly positive, and sometimes significant. Hence, we find that individuals who currently benefit from government interventions favor these interventions or are at

\footnotetext{
${ }^{25}$ Results are available from the authors upon request.

${ }^{26}$ Since almost all of the respondents report zero income for at least one of the categories, we add DM 10 of annual income to every category for every observation before we take the logarithm. Results are unchanged if we instead add DM 1 or DM 100, or if we include the incomes from different sources in levels and squared.
} 
least indifferent to them, while income from private sources has a negative effect on preferences for state intervention. Most importantly, the inclusion of these variables leaves the estimated East effects almost unchanged, and makes them even slightly stronger.

In addition to current income, expected future income may explain preferences for redistribution; individuals who expect to rise in the social ladder may oppose redistributive policies which might remain in place for several years. ${ }^{27}$ As a rough measure of the effects of expected future income, assuming perfect forecasts, we check whether the growth in income of a respondent between 1997 and 2002 affects his/her preferences in 1997. The future growth rate of income between 1997 and 2002 has a negative effect on preferences in 1997, but again its inclusion leaves the estimates of the East dummy almost unchanged (Table 7).

\subsubsection{Aggregate economic effects}

In addition to personal income, however, there might be an aggregate income effect; individuals living in regions poorer than average may prefer government intervention because of the active redistribution from richer to poorer regions, which in fact takes place in Germany.

In Table 8 we include as additional controls the average per capita income and unemployment rate of the state of residence, as well as transfers received or paid by the state; note that we continue to include as always the income of the respondent. The level of per capita income turns out never to have a significant effect. ${ }^{28}$ The regional unemployment rate has a weak positive influence on preferences for state intervention; it is only significant in the question regarding the unemployed. Financial transfers have significant positive predictive power for preferences for state intervention for the unemployed, as well as for people requiring care. After including these three

\footnotetext{
${ }^{27}$ On this point see Benabou and Ok (2001) and Alesina and La Ferrara (2005).

${ }^{28}$ Results are almost unchanged if we include the logarithm of the average per capita income, instead of the level.
} 
regional controls, in the regression regarding the unemployed the coefficient on the East indicator variable drops from 0.43 to 0.29 . This suggests that part of the East effect estimated above had to do with East German states benefitting financially from redistribution. A similar pattern occurs with all the other questions. Thus, up to one third of the "East effect" can be explained by the fact that the East became poorer during Communism and is now a net beneficiary of redistribution within Germany, rather than to an effect of Communism on preferences. The respondents' preferences for public intervention are influenced by economic effects in the region where they live, but even after controlling for that, we still find a large effect of being from the East.

\subsection{Migration and preferences}

So far, we have treated all East Germans as one homogeneous group. Yet, 7 percent of East Germans in our sample have migrated to the West. In Table 9, we add the dummy variable "East living in East", which takes on the value of 1 if an East German lives in the territory of the former East Germany in the observation year, and 0 otherwise. ${ }^{29}$

The coefficient on the East-dummy now captures the preferences of an East German living in the West. As the table shows, East Germans living in the West are more in favor of government intervention than West Germans. However, East Germans living in the East are at least twice as much in favor of government intervention than East Germans who moved to the West. This result can be interpreted in two ways. First, it could be that, having lived among West Germans for some time, preferences

\footnotetext{
${ }^{29}$ We also estimated a model in which we include instead a dummy variable "East residence" that takes on the value of 1 if the respondent lives in the East in the observation year, regardless of whether the respondent is from the former East or the former West, as well as interactions of this variable with the East dummy, the year 2002 dummy, and their interaction (results are available from the authors upon request). While this is a better modeling approach, the interpretation of the results is more complicated. Since only $0.6 \%$ of the West Germans in our sample live in the East, we hence decided to refrain from splitting the West Germans according to current residence. Results do not change significantly.
} 
of East Germans who moved to the West have converged faster than preferences of East Germans who stayed in the East. Second, those who migrated to the West could be a self-selected group that had lower preferences for state intervention to begin with. ${ }^{30}$

With regard to convergence, one can observe that all the convergence in preferences between 1997 and 2002 is driven by East Germans who stayed in the East. The preferences of East Germans who moved to the West do not change in a statistically significant way between 1997 and 2002. Again, there are several possible explanations for this phenomenon. It could be that preferences of East Germans who moved to the West converged initially, but that they have reached their new steady-state level by 2002. In this case, we should not necessarily expect full convergence either for East Germans staying in the East. On the other hand, it could be that those East Germans who moved to the West not only had different preferences at the time of migration, but that their preferences also exhibit different convergence patterns. In the case of preferences regarding financial security when unemployed and financial security of old individuals and families, East Germans who moved to the West even become more pro state over time, although this effect is not statistically significant; ${ }^{31}$ this might be interpreted as a backlash of preferences after experiencing life in the West.

\subsection{Differences across regions and along other attributes}

In order to gain further insides whether the measured effect really captures the effect of Communism, we analyze the homogeneity of the effect along different attributes. We would expect the effect of Communism to be relatively homogeneous across eastern states, as well as across different groups of the population (e.g. male vs. female individuals). Hence, we would be worried if the "East" effect on preferences were

\footnotetext{
${ }^{30}$ Note e.g. that the average age of East respondents who moved to the West is 34 , while the average age of East respondents who stayed in the East is 45.

${ }^{31}$ The associated p-values are $0.17,0.38$ and 0.95 .
} 
very heterogeneous, and especially if we only detected it in one or two single states, or in specific groups of the population.

First, we rerun our baseline regression including separate dummies for all 5 eastern states plus East Berlin instead of one single East dummy. Note that, consistent with the East dummy, these dummies refer to the state of residence at the time of reunification. As the results in Table 10 show, the coefficients on the eastern state dummies are positive and significant in all states. Moreover, they are of similar size across the states. The only slight outlier that emerges is the state of MecklenburgVorpommern, which is in 4 out of 5 cases more pro private forces than the other eastern states, although it is still relatively pro-government compared with West Germany. With regard to convergence, the results are a little bit more heterogeneous. However, only 5 out of 30 coefficients on the interaction term between an East German state and the year 2002 turn out not to be negative, while 15 of the 30 coefficients are significantly negative. Every state shows significant convergence in at least 1 of the 5 questions.

We redo this exercise on the even smaller units of Raumordnungsregionen (see section 3). ${ }^{32}$ While many of the coefficients are not significant, which is not surprising given the smaller number of observations per unit, the results are quite homogeneous across the regions. ${ }^{33}$

To analyze the homogeneity of the effect of Communism on preferences across different groups, we create interactions of all the independent variables with the Eastdummy, and include all interaction terms as further controls. ${ }^{34}$ Thus, we can test whether the effect of a certain characteristic on preferences for state intervention is significantly different in the East from the effect in the West. Strikingly, the only characteristic for which this is consistently the case is age, as we would expect and

\footnotetext{
${ }^{32}$ Results are available from the authors upon request.

${ }^{33}$ The only outlier that emerges is the region Prignitz, which always has an insignificantly negative coefficient on its dummy variable, and shows convergence only in 2 out of the 5 categories.

${ }^{34}$ Results are available from the authors upon request.
} 
detected before (see the analysis in section 3.1). Only 8 out of the other 105 coefficients on interaction terms (21 interaction terms in 5 regressions) are statistically significant, but never consistently across the five different regressions. ${ }^{35}$

Thus, we conclude that the effect of Communism on preferences is homogeneous across eastern states, and across different groups of the East German population (with the exception of age groups). This makes it even more likely that we capture the effect of Communism, rather than some aggregate or individual economic effects, given that the experience of transition has not been uniform across eastern regions and different population groups.

\section{Social conditions, individual effort and luck}

Why do former East Germans favor state intervention? One possibility is that they are used to think (partly because of the influence of Communist ideology) that it is "society's fault" if people are poor, unemployed or in need of help. If the individual is not responsible, but society is, then society (i.e. the state) should take care of these problems.

In Table 11 we report a regression in which the left hand side is a variable that takes the value of 1 if the respondent believes that social conditions determine individual possibilities in life. In column 1, we find a strong effect of being from the East. The probability of believing in the influence of social conditions is 11 percentage points higher for an East German than a West German. In the next column we interact the East indicator variable with the age of the respondent and find, once again, a strong age effect. ${ }^{36}$ Older East Germans are more likely to believe in social conditions as major determinants of individual fortunes than younger East Germans. We interpret

\footnotetext{
${ }^{35}$ Being married has a statistically significantly different effect in East and West in two out of the five regressions, as has belonging to the group of "other nonworking". For being male, self-employed, retired, or having intermediate or technical school as highest education, this is the case in only one out of the five regressions. The results are unchanged whether we include higher order terms of age (and their interactions) or not.

${ }^{36} \mathrm{As}$ in table 3 , we omit higher order terms of age as controls in this regression.
} 
this as the effect of having lived longer under a Communist regime. In the West, the age effect is not significant.

Table 12 however shows that the effect of having lived in the East goes well beyond these beliefs about social conditions. In this table (where as always we control for all individual characteristics), we repeat the baseline regression including the dummy variable capturing beliefs in an important role of social conditions as control. While the variable capturing the beliefs about social conditions has a significantly positive influence on preferences for an active state role, the East indicator variables are still significant and only slightly smaller than in the baseline results in Table 1 . Thus, even after controlling for beliefs regarding social conditions, former East Germans believe in state intervention more than former West Germans.

Alesina and La Ferrara (2005) and Alesina and Glaeser (2004) find that those who believe that luck determines wealth and success in life are more pro redistribution than those who belief that mostly individual effort is responsible for success. ${ }^{37} \mathrm{We}$ pursue this line here as well. Table 13 shows a regression in which the left hand side variable is defined as 1 if the respondent believes that luck determines individual fortunes. The East indicator variable is now negative. If we put this result together with that of Table 11, it appears that East Germans believe more than West Germans that individuals (being their effort or their luck) matter less than social conditions in determining success or failure in life. Column 2 shows no age effect for East Germans beyond the positive age effect also observed for West Germans. ${ }^{38}$ Table 14 shows that those who belief that luck matters a lot in determining individual success are more favorable to government intervention. Not surprisingly, given the lower belief in the role of luck by East Germans, the inclusion of this variable has no significant effect on the east indicator variable.

\footnotetext{
${ }^{37}$ Alesina and Angeletos (2005) and Benabou and Tirole (2005) present models seeking to explain the equilibrium redistributive policies as a function of individual beliefs about luck and effort as determinants of success.

${ }^{38}$ Again, we omit higher order terms of age as controls in this regression.
} 


\section{Final remarks}

We find that East Germans are much more pro-state than West Germans. According to our results, it will take about one to two generations (20 to 40 years) for an average East German to have the same views on state intervention as an average West German. The difference in preferences between former East and West Germans is due in large part to the direct effect of Communism. This effect could arise due to indoctrination, e.g. in public schools, or simply due to becoming used to an intrusive public sector. A second, indirect effect of Communism is that by making former East Germany poorer than West Germany, it has made the former more dependent on redistribution and therefore more favorable to it.

Former West Germany has then received a major "political shock", in the sense that the new members of the unified Germany are much more favorable to state intervention. This shock has potentially long-lasting effects, since we find that preferences need one to two generations to converge.

In evaluating these results, one always has to wonder whether or not survey answers are meaningful, namely whether they reflect what individuals truly believe (Bertrand and Mullainathan, 2001). We are quite confident that they truly reflect

preferences for two reasons. First, the basic correlations of the answers with variables like income, wealth, and labor force status are consistent with obvious individual cost/benefit analyses. Second, evidence on voting behavior in East and West over the observation period is consistent with the picture emerging from this survey. Table A6 shows the share of votes obtained by various parties in the different states in the elections for the federal parliament (Bundestagswahlen) in 1998 and 2002. In this table, the parties are ordered from left to right to coincide with their position in the political spectrum. Thus, the first column shows the vote share per state of the most leftist party, the PDS (Partei des Demokratischen Sozialismus), which is in effect the successor party of the SED (Sozialistische Einheitspartei Deutschlands), the ruling 
party in the GDR. In 1998, the percentage of votes received by this party was about 20 per cent in the East, but only around 1 to 2 per cent in the West; it was around 10 per cent in Berlin, which includes both former East and former West Berlin. This is consistent with our finding of a much more pro state, left leaning population in the East, as captured by the survey. Also, comparing the 2002 and 1998 elections, we see how the percentage of the PDS votes in the East shrinks substantially, presumably in favor of the SPD, the main center left party, whose share increases almost identically to the reduction in votes for the PDS. This indicates a movement away from the communist leaning left toward the center of the political spectrum, and shows a convergence of the East to the West. This voting behavior is therefore consistent with the preferences regarding state intervention expressed by the respondents of the survey.

In summary, we provide evidence that individuals' preferences are rather deeply shaped by the political regime in which they live.

\section{References}

[1] Ai, Chunrong and Edward C. Norton (2003): Interaction Terms in Logit and Probit Models, Economics Letters, 80, 123-129.

[2] Alesina, Alberto and George-Marios Angeletos (2005): Fairness and Redistribution, American Economic Review, forthcoming.

[3] Alesina, Alberto and Edward L. Glaeser (2004): Fighting Poverty in the U.S. and Europe: A World of Difference, Oxford University Press, Oxford, UK.

[4] Alesina, Alberto and Eliana La Ferrara (2005): Preferences for Redistribution in the Land of Opportunities, Journal of Public Economics, 89, 897-931.

[5] Barro, Robert J. and Rachel M. McCleary (2005): Which Countries have State Religions?, mimeo, Harvard University.

[6] Benabou, Roland and Efe A. Ok (2001): Social Mobility and the Demand for Redistribution: The POUM Hypothesis, Quarterly Journal of Economics, 116(2), 447-487. 
[7] Benabou, Roland and Jean Tirole (2005): Belief in a Just World and Redistributive Policies, mimeo, Princeton University.

[8] Bertrand, Marianne, and Sendhil Mullainathan (2001): Do People Mean What They Say? Implications for Subjective Survey Data, American Economic Review Papers $\&$ Proceedings, 91(2), 67-72.

[9] Blanchflower, David G. and Richard B. Freeman (1997): The Attitudinal Legacy of Communist Labor Relations, Industrial and Labor Relations Review, 50(3), $438-459$.

[10] Corneo, Giacomo (2001): Inequality and the State: Comparing US and German Preferences, Annales d'Economie et de Statistique, 63-64, 283-296.

[11] Corneo, Giacomo and Hans Peter Grüner (2002): Individual Preferences for Political Redistribution, Journal of Public Economics, 83, 83-107.

[12] Fong, Christina (2003): The Tunnel Effect Conjecture, the POUM Hypothesis, and the Behavioral Assumptions of Economics, mimeo, Carnegie Mellon University.

[13] Fuchs-Schündeln, Nicola and Matthias Schündeln (2005): Precautionary Savings and Self-Selection: Evidence from the German Reunification "Experiment", Quarterly Journal of Economics, 120(3), 1085-1120.

[14] Giavazzi, Francesco and Michael McMahon (2005): All Talk, No Action: The Effects of Reforms that are Long Discussed but Never Implemented, mimeo, Bocconi University.

[15] Heidemeyer, Helge (1994): Flucht und Zuwanderung aus der SBZ/DDR 1945/1949-1961, Droste Verlag, Düsseldorf.

[16] McCleary, Rachel M. and Robert J. Barro (2003): Religion and Political Economy in an International Panel, mimeo, Harvard University.

[17] Münz, Rainer, and Ralf Ulrich (1997): Changing Patterns of Immigration to Germany, 1945-1995: Ethnic Origins, Demographic Structure, Future Prospects, in: Bade, Klaus J. and Myron Weiner (eds.): Migration Past, Migration Future: Germany and the United States, Volume 1, Berghahn Books, Providence, Oxford.

[18] Ockenfels, Axel and Joachim Weimann (1999): Types and Patterns: An Experimental East-West-German Comparison of Cooperation and Solidarity, Journal of Public Economics, 71, 275-287.

[19] Piketty, Thomas (1995): Social Mobility and Redistributive Politics, Quarterly Journal of Economics, 110, 551-584. 
[20] Ravallion, Martin and Michael Lokshin (2000): Who Wants to Redistribute? The Tunnel Effect in 1990 Russia, Journal of Public Economics, 76, 87-104.

[21] Rytlewski, Ralf and Manfred Opp de Hipt (1987): Die Deutsche Demokratische Republik in Zahlen, 1945/49-1980, Verlag H.C. Beck, München.

[22] Schäfgen, Katrin (1998): Die Verdoppelung der Ungleichheit. Sozialstruktur und Geschlechterverhältnisse in der Bundesrepublik und in der DDR, Dissertation, Humboldt-Universität.

[23] Schumann, Karl F., Gerhard-Uhland Dietz, Manfred Gehrmann, Heidi Kaspras and Olaf Struck-Möbbeck (1996): Private Wege der Wiedervereinigung. Die deutsche Ost-West-Migration vor der Wende, Deutscher Studienverlag, Weinheim.

[24] Shiller, Robert J., Maxim Boycko, and Vladimir Korobov (1992): Hunting for Homo Sovieticus: Situational versus Attitudinal Factors in Economic Behavior, Brookings Papers on Economic Activity, 1992/1, 127-194.

[25] Shiller, Robert J., Maxim Boycko, and Vladimir Korobov (1991): Popular Attitudes Toward Free Markets: The Soviet Union and the United States Compared, American Economic Review, 81(3), 385-400.

[26] Statistisches Jahrbuch für das Deutsche Reich, various issues.

[27] Stephan, Helga and Eberhard Wiedemann (1990): Lohnstruktur und Lohndifferenzierung in der DDR: Ergebnisse der Lohndatenerfassung vom September 1988, Mitteilungen aus der Arbeitsmarkt- und Berufsforschung, 23, 550-562.

[28] Storbeck, Dietrich (1963): Flucht oder Wanderung, Soziale Welt, 14, 153-171. 


\section{Appendix}

\section{A German regional transfer system}

German federalism is a complicated structure, with many legislative areas and taxes shared between the federal government and the states. Realizing the different economic powers of the states, the need for an equalization scheme was written down in the West German constitution in 1949. In 1993, federal and state governments reformed the system to administer massive monetary flows into the new eastern German states. The new system (Solidarpakt I) was established in 1995, and scheduled to expire at the end of 2004. In response to the still significant economic needs of the eastern German states, the federal and state governments negotiated an extension of the system (Solidarpakt II) in 2001, which started to become effective in 2005 and is scheduled to expire at the end of 2019. Through the new system, the eastern German states will receive a total of 306 billion DM (i.e. 156 billion Euro) over a period of 15 years.

The financial equalization scheme between the federal government and the states (Länderfinanzausgleich) comprises a horizontal and a vertical component. In the horizontal component, the financial needs and financial resources of any given state are determined via specific formulas. Based on these calculations, it is decided whether a given state should receive extra financial resources, or should share its resources with other states. The financial flows between the states in this step sum up to zero. ${ }^{39}$ In the subsequent vertical component, certain states receive additional financial resources from the federal government (Bundesergänzungszuweisungen). On top of that, since 1995 the eastern German states have received special support from the federal government based on the "law for the promotion of investment in eastern Germany" (Investitionsförderungsgesetz Aufbau Ost). Last, the debt of the East German government was taken over by the western German states. This led to annual interest and amortization payments by only the western states (Fonds Deutsche Einheit). In Table A4, we report the transfers per capita in DM for every state in 1997 and 2002, adding the vertical and the horizontal component of the Länderfinanzausgleich, as well as the flows based on the Investitionsförderungsgeset $z^{40}$ and the Fonds Deutsche Einheit. ${ }^{41}$

\footnotetext{
${ }^{39}$ In a preceding step, the receipts from value added taxes are divided between the states. $75 \%$ of the receipts are divided based on the number of inhabitants, while $25 \%$ of the receipts are divided according to a formula that takes the financial needs of the states into account. Hence, this procedure leads to some implicit flows between states. Unfortunately, we were not able to obtain the amounts of these implicit transfers.

${ }^{40}$ Since 2002, these flows have become part of the Bundesergänzungszuweisungen, and hence they have only been added in 1997.

${ }^{41}$ Note that results are unchanged when we omit the Fonds Deutsche Einheit in calculating the transfers.
} 
Table 1: Basic regression

\begin{tabular}{|c|c|c|c|c|c|c|c|c|c|c|}
\hline \multirow[t]{2}{*}{ Dependent variable } & \multicolumn{2}{|c|}{$\begin{array}{l}\text { Responsibility for the } \\
\text { financial security when } \\
\text { unemployed (state=1) }\end{array}$} & \multicolumn{2}{|c|}{$\begin{array}{l}\text { Responsibility for the } \\
\text { financial security when } \\
\text { sick (state=1) }\end{array}$} & \multicolumn{2}{|c|}{$\begin{array}{l}\text { Responsibility for the } \\
\text { financial security of the } \\
\text { family (state=1) }\end{array}$} & \multicolumn{2}{|c|}{$\begin{array}{l}\text { Responsibility for the } \\
\text { financial security when } \\
\text { old (state=1) }\end{array}$} & \multicolumn{2}{|c|}{$\begin{array}{l}\text { Responsibility for the } \\
\text { financial security when } \\
\text { requiring care (state=1) }\end{array}$} \\
\hline & Coeff. & Std. Err. & Coeff. & Std. Err. & Coeff. & Std. Err. & Coeff. & Std. Err. & Coeff. & Std. Err. \\
\hline east & 0.432 & 0.030 & 0.434 & 0.028 & 0.420 & 0.028 & 0.426 & 0.028 & 0.371 & 0.028 \\
\hline year02 & 0.064 & 0.023 & 0.165 & 0.023 & -0.012 & 0.024 & -0.033 & 0.023 & 0.103 & 0.023 \\
\hline east ${ }^{\star}$ year02 & -0.123 & 0.039 & -0.161 & 0.036 & -0.060 & 0.036 & -0.143 & 0.036 & -0.176 & 0.036 \\
\hline age & -0.026 & 0.015 & -0.005 & 0.015 & -0.009 & 0.015 & -0.019 & 0.014 & -0.003 & 0.014 \\
\hline age squared & 0.001 & 0.000 & 0.000 & 0.000 & 0.000 & 0.000 & 0.000 & 0.000 & 0.000 & 0.000 \\
\hline age cubed & 0.000 & 0.000 & 0.000 & 0.000 & 0.000 & 0.000 & -0.000 & 0.000 & 0.000 & 0.000 \\
\hline college & -0.203 & 0.064 & -0.258 & 0.061 & -0.141 & 0.062 & -0.277 & 0.061 & -0.122 & 0.060 \\
\hline vocational training & -0.096 & 0.057 & -0.140 & 0.054 & -0.136 & 0.055 & -0.163 & 0.054 & -0.087 & 0.054 \\
\hline secondary schooling & -0.101 & 0.059 & -0.071 & 0.056 & -0.023 & 0.057 & -0.103 & 0.056 & -0.068 & 0.056 \\
\hline intermediate schooling & -0.103 & 0.069 & -0.152 & 0.066 & -0.147 & 0.068 & -0.155 & 0.065 & -0.052 & 0.065 \\
\hline male & -0.083 & 0.023 & -0.072 & 0.022 & -0.003 & 0.022 & -0.020 & 0.022 & 0.020 & 0.021 \\
\hline number of children & 0.034 & 0.014 & 0.034 & 0.012 & 0.064 & 0.012 & 0.038 & 0.012 & 0.010 & 0.012 \\
\hline number of adults & 0.022 & 0.013 & 0.043 & 0.012 & 0.022 & 0.011 & 0.037 & 0.011 & 0.007 & 0.012 \\
\hline married & 0.069 & 0.039 & 0.106 & 0.037 & 0.026 & 0.037 & 0.045 & 0.036 & 0.109 & 0.036 \\
\hline divorced & 0.089 & 0.052 & 0.048 & 0.051 & 0.042 & 0.050 & 0.047 & 0.050 & 0.107 & 0.049 \\
\hline married but separated & 0.011 & 0.087 & -0.028 & 0.083 & -0.042 & 0.083 & 0.082 & 0.084 & 0.161 & 0.084 \\
\hline widowed & -0.050 & 0.060 & 0.027 & 0.058 & -0.043 & 0.059 & -0.038 & 0.057 & 0.075 & 0.057 \\
\hline $\log$ (household income) & -0.156 & 0.027 & -0.264 & 0.025 & -0.135 & 0.025 & -0.224 & 0.025 & -0.148 & 0.025 \\
\hline civil servant & -0.122 & 0.057 & -0.222 & 0.059 & 0.085 & 0.059 & -0.060 & 0.059 & -0.113 & 0.055 \\
\hline self-employed & -0.317 & 0.052 & -0.403 & 0.053 & -0.332 & 0.053 & -0.450 & 0.053 & -0.306 & 0.051 \\
\hline white-collar worker & -0.030 & 0.033 & -0.044 & 0.032 & 0.011 & 0.032 & -0.089 & 0.031 & -0.101 & 0.031 \\
\hline unemployed & 0.161 & 0.051 & 0.005 & 0.047 & 0.142 & 0.047 & 0.005 & 0.046 & -0.034 & 0.046 \\
\hline retired & -0.075 & 0.059 & -0.090 & 0.057 & 0.149 & 0.058 & 0.019 & 0.056 & 0.011 & 0.056 \\
\hline maternity & 0.015 & 0.080 & -0.051 & 0.077 & 0.119 & 0.075 & -0.197 & 0.077 & -0.081 & 0.075 \\
\hline nonworking & -0.027 & 0.043 & -0.022 & 0.042 & 0.158 & 0.042 & -0.012 & 0.041 & 0.021 & 0.041 \\
\hline training & -0.049 & 0.066 & -0.021 & 0.063 & -0.115 & 0.065 & -0.086 & 0.063 & -0.021 & 0.063 \\
\hline other nonworking & -0.000 & 0.052 & -0.093 & 0.049 & 0.062 & 0.049 & -0.046 & 0.049 & -0.097 & 0.049 \\
\hline constant & 1.994 & 0.303 & 1.852 & 0.293 & 0.728 & 0.293 & 1.859 & 0.291 & 1.178 & 0.287 \\
\hline obs & 18,489 & & 18,487 & & 18,485 & & 18,516 & & 18,514 & \\
\hline log likelihood & $-11,060$ & & $-12,192$ & & $-11,954$ & & $-12,250$ & & $-12,568$ & \\
\hline
\end{tabular}

Note: Probit regressions. Omitted categories are less than 9 years of schooling, female, single, blue-collar worker, and employed. 


\section{Table 2: Basic regression with asset controls}

\begin{tabular}{|c|c|c|c|c|c|c|c|c|c|c|}
\hline \multirow[t]{2}{*}{ Dependent variable } & \multicolumn{2}{|c|}{$\begin{array}{c}\text { Responsibility for } \\
\text { the financial security } \\
\text { when unemployed } \\
\text { (state=1) }\end{array}$} & \multicolumn{2}{|c|}{$\begin{array}{l}\text { Responsibility for the } \\
\text { financial security } \\
\text { when sick (state=1) }\end{array}$} & \multicolumn{2}{|c|}{$\begin{array}{l}\text { Responsibility for the } \\
\text { financial security of } \\
\text { the family (state }=1 \text { ) }\end{array}$} & \multicolumn{2}{|c|}{$\begin{array}{c}\text { Responsibility for the } \\
\text { financial security } \\
\text { when old (state }=1 \text { ) }\end{array}$} & \multicolumn{2}{|c|}{$\begin{array}{c}\text { Responsibility for the } \\
\text { financial security } \\
\text { when requiring care } \\
\text { (state=1) }\end{array}$} \\
\hline & Coeff. & Std. Err. & Coeff. & Std. Err. & Coeff. & Std. Err. & Coeff. & Std. Err. & Coeff. & Std. Err. \\
\hline east & 0.412 & 0.032 & 0.404 & 0.030 & 0.399 & 0.030 & 0.406 & 0.030 & 0.357 & 0.030 \\
\hline year02 & 0.088 & 0.025 & 0.180 & 0.025 & -0.009 & 0.026 & -0.005 & 0.025 & 0.125 & 0.025 \\
\hline east ${ }^{\star}$ year02 & -0.129 & 0.041 & -0.155 & 0.039 & -0.067 & 0.039 & -0.146 & 0.038 & -0.195 & 0.039 \\
\hline $\log$ (household asset income) & -0.029 & 0.009 & -0.030 & 0.009 & -0.017 & 0.009 & -0.049 & 0.039 & -0.028 & 0.009 \\
\hline own house & -0.080 & 0.023 & -0.062 & 0.023 & -0.153 & 0.023 & -0.119 & 0.023 & -0.113 & 0.023 \\
\hline age & -0.028 & 0.016 & -0.023 & 0.016 & -0.018 & 0.016 & -0.035 & 0.016 & -0.021 & 0.016 \\
\hline age squared $\left({ }^{*} 10^{3}\right)$ & 0.681 & 0.328 & 0.510 & 0.317 & 0.433 & 0.321 & 0.750 & 0.316 & 0.331 & 0.314 \\
\hline age cubed $\left({ }^{*} 10^{3}\right)$ & 0.004 & 0.002 & -0.003 & 0.002 & -0.003 & 0.002 & -0.005 & 0.002 & -0.002 & 0.002 \\
\hline college & -0.208 & 0.071 & -0.225 & 0.067 & -0.135 & 0.068 & -0.264 & 0.067 & -0.080 & 0.066 \\
\hline vocational training & -0.115 & 0.064 & -0.129 & 0.061 & -0.140 & 0.062 & -0.160 & 0.060 & -0.047 & 0.060 \\
\hline secondary schooling & -0.143 & 0.066 & -0.072 & 0.062 & -0.045 & 0.064 & -0.104 & 0.062 & -0.051 & 0.062 \\
\hline intermediate schooling & -0.091 & 0.076 & -0.125 & 0.072 & -0.150 & 0.075 & -0.139 & 0.072 & -0.021 & 0.072 \\
\hline male & -0.102 & 0.024 & -0.076 & 0.023 & -0.008 & 0.023 & -0.023 & 0.023 & 0.014 & 0.023 \\
\hline number of children & 0.035 & 0.015 & 0.039 & 0.013 & 0.077 & 0.013 & 0.050 & 0.013 & 0.018 & 0.013 \\
\hline number of adults & 0.024 & 0.014 & 0.044 & 0.012 & 0.037 & 0.012 & 0.045 & 0.012 & 0.013 & 0.012 \\
\hline married & 0.062 & 0.041 & 0.117 & 0.039 & 0.028 & 0.039 & 0.050 & 0.039 & 0.126 & 0.038 \\
\hline divorced & 0.058 & 0.058 & 0.045 & 0.057 & 0.037 & 0.057 & 0.005 & 0.057 & 0.093 & 0.055 \\
\hline married but separated & -0.096 & 0.102 & -0.112 & 0.098 & -0.002 & 0.097 & 0.030 & 0.098 & 0.184 & 0.097 \\
\hline widowed & -0.056 & 0.065 & 0.020 & 0.062 & -0.062 & 0.064 & -0.055 & 0.062 & 0.098 & 0.061 \\
\hline $\log$ (household income) & -0.129 & 0.030 & -0.244 & 0.029 & -0.092 & 0.029 & -0.169 & 0.028 & -0.103 & 0.028 \\
\hline civil servant & -0.094 & 0.059 & -0.198 & 0.061 & 0.084 & 0.061 & -0.020 & 0.061 & -0.082 & 0.057 \\
\hline self-employed & -0.260 & 0.055 & -0.356 & 0.056 & -0.322 & 0.058 & -0.431 & 0.057 & -0.254 & 0.054 \\
\hline white-collar worker & -0.016 & 0.035 & -0.028 & 0.034 & 0.013 & 0.034 & -0.072 & 0.033 & -0.091 & 0.033 \\
\hline unemployed & 0.181 & 0.057 & 0.028 & 0.053 & 0.150 & 0.053 & 0.047 & 0.053 & -0.035 & 0.052 \\
\hline retired & -0.072 & 0.063 & -0.119 & 0.061 & 0.130 & 0.062 & 0.028 & 0.060 & 0.005 & 0.060 \\
\hline maternity & -0.008 & 0.087 & -0.010 & 0.065 & 0.105 & 0.082 & -0.207 & 0.086 & -0.033 & 0.084 \\
\hline nonworking & -0.015 & 0.047 & -0.008 & 0.045 & 0.155 & 0.045 & 0.012 & 0.045 & 0.023 & 0.044 \\
\hline training & -0.008 & 0.072 & -0.003 & 0.069 & -0.093 & 0.071 & -0.063 & 0.069 & 0.043 & 0.068 \\
\hline other nonworking & 0.027 & 0.055 & -0.065 & 0.053 & 0.064 & 0.053 & -0.005 & 0.053 & -0.061 & 0.053 \\
\hline constant & 2.010 & 0.334 & 2.128 & 0.325 & 0.626 & 0.324 & 1.928 & 0.320 & 1.198 & 0.317 \\
\hline obs & 16,260 & & 16,257 & & 16,255 & & 16,282 & & 16,278 & \\
\hline log likelihood & $-9,762$ & & $-10,683$ & & $-10,458$ & & $-10,693$ & & $-11,020$ & \\
\hline
\end{tabular}

Note: Probit regressions. Omitted categories are less than 9 years of schooling, female, single, blue-collar worker, and employed. 


\section{Table 3: Regressions with east*age interaction}

\begin{tabular}{|c|c|c|c|c|c|c|c|c|c|c|}
\hline \multirow[t]{2}{*}{ Dependent variable } & \multicolumn{2}{|c|}{$\begin{array}{l}\text { Responsibility for the } \\
\text { financial security when } \\
\text { unemployed (state }=1 \text { ) }\end{array}$} & \multicolumn{2}{|c|}{$\begin{array}{l}\text { Responsibility for the } \\
\text { financial security when } \\
\text { sick (state }=1 \text { ) }\end{array}$} & \multicolumn{2}{|c|}{$\begin{array}{l}\text { Responsibility for the } \\
\text { financial security of the } \\
\text { family (state }=1 \text { ) }\end{array}$} & \multicolumn{2}{|c|}{$\begin{array}{l}\text { Responsibility for the } \\
\text { financial security when } \\
\text { old (state=1) }\end{array}$} & \multicolumn{2}{|c|}{$\begin{array}{l}\text { Responsibility for the } \\
\text { financial security when } \\
\text { requiring care (state=1) }\end{array}$} \\
\hline & Coeff. & Std. Err. & Coeff. & Std. Err. & Coeff. & Std. Err. & Coeff. & Std. Err. & Coeff. & Std. Err. \\
\hline east & 0.029 & 0.064 & -0.034 & 0.060 & -0.032 & 0.060 & -0.226 & 0.060 & 0.002 & 0.059 \\
\hline year02 & 0.070 & 0.023 & 0.172 & 0.023 & -0.006 & 0.024 & -0.024 & 0.023 & 0.108 & 0.023 \\
\hline east ${ }^{*}$ year02 & -0.139 & 0.039 & -0.176 & 0.036 & -0.074 & 0.037 & -0.168 & 0.036 & -0.189 & 0.036 \\
\hline age & -0.000 & 0.001 & -0.002 & 0.001 & -0.003 & 0.001 & -0.003 & 0.001 & -0.005 & 0.001 \\
\hline east*age & 0.009 & 0.001 & 0.011 & 0.001 & 0.010 & 0.001 & 0.015 & 0.001 & 0.008 & 0.001 \\
\hline obs & 18,489 & & 18,487 & & 18,485 & & 18,516 & & 18,514 & \\
\hline log likelihood & $-11,034$ & & $-12,148$ & & $-11,914$ & & $-12,165$ & & $-12,541$ & \\
\hline
\end{tabular}

Note: Probit regressions. Included as controls are number of children and number of adults in household, logarithm of household income, and dummies for education, sex, marital status, employment status, and occupation.

Table 4: Regressions with cohorts interacted with east

\begin{tabular}{|c|c|c|c|c|c|c|c|c|c|c|}
\hline \multirow[t]{2}{*}{ Dependent variable } & \multicolumn{2}{|c|}{$\begin{array}{l}\text { Responsibility for the } \\
\text { financial security when } \\
\text { unemployed (state }=1 \text { ) }\end{array}$} & \multicolumn{2}{|c|}{$\begin{array}{l}\text { Responsibility for the } \\
\text { financial security when } \\
\text { sick (state=1) }\end{array}$} & \multicolumn{2}{|c|}{$\begin{array}{l}\text { Responsibility for the } \\
\text { financial security of the } \\
\text { family (state=1) }\end{array}$} & \multicolumn{2}{|c|}{$\begin{array}{l}\text { Responsibility for the } \\
\text { financial security when } \\
\text { old (state }=1 \text { ) }\end{array}$} & \multicolumn{2}{|c|}{$\begin{array}{l}\text { Responsibility for the } \\
\text { financial security when } \\
\text { requiring care (state=1) }\end{array}$} \\
\hline & Coeff. & Std. Err. & Coeff. & Std. Err. & Coeff. & Std. Err. & Coeff. & Std. Err. & Coeff. & Std. Err. \\
\hline east & 0.318 & 0.068 & 0.246 & 0.063 & 0.147 & 0.064 & 0.081 & 0.064 & 0.205 & 0.064 \\
\hline year02 & 0.066 & 0.026 & 0.162 & 0.026 & -0.045 & 0.027 & -0.066 & 0.026 & 0.105 & 0.025 \\
\hline east ${ }^{*}$ year02 & -0.111 & 0.039 & -0.137 & 0.037 & -0.033 & 0.037 & -0.107 & 0.036 & -0.156 & 0.036 \\
\hline born 1961-1975 & 0.014 & 0.074 & 0.018 & 0.070 & -0.204 & 0.072 & -0.215 & 0.072 & -0.027 & 0.070 \\
\hline born 1946-1960 & -0.092 & 0.100 & -0.061 & 0.095 & -0.431 & 0.097 & -0.391 & 0.096 & -0.086 & 0.094 \\
\hline born 1931-1945 & -0.064 & 0.127 & -0.105 & 0.122 & -0.488 & 0.124 & -0.517 & 0.123 & -0.092 & 0.120 \\
\hline born before 1931 & -0.008 & 0.155 & -0.104 & 0.149 & -0.420 & 0.151 & -0.467 & 0.151 & -0.006 & 0.146 \\
\hline born $1961-1975^{\star}$ east & -0.106 & 0.075 & -0.007 & 0.071 & 0.120 & 0.071 & 0.128 & 0.072 & 0.012 & 0.071 \\
\hline born 1946-1960east & 0.169 & 0.077 & 0.180 & 0.072 & 0.286 & 0.073 & 0.314 & 0.073 & 0.152 & 0.073 \\
\hline born $1931-1945^{\star}$ east & 0.356 & 0.081 & 0.392 & 0.075 & 0.501 & 0.076 & 0.643 & 0.076 & 0.365 & 0.076 \\
\hline born before $1931^{*}$ east & 0.303 & 0.099 & 0.458 & 0.091 & 0.454 & 0.090 & 0.754 & 0.091 & 0.391 & 0.090 \\
\hline obs & 18,489 & & 18,487 & & 18,485 & & 18,516 & & 18,514 & \\
\hline log likelihood & $-11,021$ & & $-12,152$ & & $-11,905$ & & $-12,162$ & & $-12,534$ & \\
\hline
\end{tabular}

Note: Probit regressions. Included as controls are cubic function in age, number of children and number of adults in household, logarithm of household income, and dummies for education, sex, marital status, employment status, and occupation. 
Table 5: Regressions with individuals who answer in 1997 and 2002

\begin{tabular}{|c|c|c|c|c|c|c|c|c|c|c|}
\hline \multirow[t]{2}{*}{ Dependent variable } & \multicolumn{2}{|c|}{$\begin{array}{l}\text { Responsibility for the } \\
\text { financial security when } \\
\text { unemployed (state=1) }\end{array}$} & \multicolumn{2}{|c|}{$\begin{array}{l}\text { Responsibility for the } \\
\text { financial security when } \\
\text { sick (state=1) }\end{array}$} & \multicolumn{2}{|c|}{$\begin{array}{l}\text { Responsibility for the } \\
\text { financial security of the } \\
\text { family (state=1) }\end{array}$} & \multicolumn{2}{|c|}{$\begin{array}{l}\text { Responsibility for the } \\
\text { financial security when } \\
\text { old (state=1) }\end{array}$} & \multicolumn{2}{|c|}{$\begin{array}{l}\text { Responsibility for the } \\
\text { financial security when } \\
\text { requiring care (state=1) }\end{array}$} \\
\hline & Coeff. & Std. Err. & Coeff. & Std. Err. & Coeff. & Std. Err. & Coeff. & Std. Err. & Coeff. & Std. Err. \\
\hline east & 0.446 & 0.035 & 0.394 & 0.033 & 0.407 & 0.033 & 0.391 & 0.033 & 0.333 & 0.033 \\
\hline year02 & 0.052 & 0.026 & 0.164 & 0.026 & -0.032 & 0.027 & -0.048 & 0.026 & 0.095 & 0.025 \\
\hline east*year02 & -0.124 & 0.043 & -0.109 & 0.040 & -0.022 & 0.040 & -0.067 & 0.039 & -0.130 & 0.040 \\
\hline obs & 14,110 & & 14,110 & & 14,110 & & 14,110 & & 14,110 & \\
\hline log likelihood & $-8,414$ & & $-9,321$ & & $-9,131$ & & $-9,323$ & & $-9,576$ & \\
\hline
\end{tabular}

Note: Probit regressions. Included as controls are cubic function in age, number of children and number of adults in household, logarithm of household income, and dummies for education, sex, marital status, employment status, and occupation.

\section{Table 6: Regressions with income sources}

\begin{tabular}{|c|c|c|c|c|c|c|c|c|c|c|}
\hline \multirow[t]{2}{*}{ Dependent variable } & \multicolumn{2}{|c|}{$\begin{array}{c}\text { Responsibility for } \\
\text { the financial security } \\
\text { when unemployed } \\
\text { (state=1) }\end{array}$} & \multicolumn{2}{|c|}{$\begin{array}{c}\text { Responsibility for } \\
\text { the financial security } \\
\text { when sick (state=1) }\end{array}$} & \multicolumn{2}{|c|}{$\begin{array}{c}\text { Responsibility for } \\
\text { the financial security } \\
\text { of the family } \\
\text { (state=1) }\end{array}$} & \multicolumn{2}{|c|}{$\begin{array}{l}\text { Responsibility for } \\
\text { the financial security } \\
\text { when old (state=1) }\end{array}$} & \multicolumn{2}{|c|}{$\begin{array}{c}\text { Responsibility for } \\
\text { the financial security } \\
\text { when requiring care } \\
(\text { state }=1)\end{array}$} \\
\hline & Coeff. & Std. Err. & Coeff. & Std. Err. & Coeff. & Std. Err. & Coeff. & Std. Err. & Coeff. & Std. Err. \\
\hline east & 0.448 & 0.030 & 0.468 & 0.028 & 0.437 & 0.028 & 0.459 & 0.028 & 0.396 & 0.028 \\
\hline year02 & 0.050 & 0.023 & 0.146 & 0.023 & -0.023 & 0.024 & -0.055 & 0.024 & 0.089 & 0.023 \\
\hline east*year02 & -0.128 & 0.039 & -0.176 & 0.037 & -0.069 & 0.037 & -0.145 & 0.036 & -0.184 & 0.036 \\
\hline pension income & 0.007 & 0.006 & 0.002 & 0.005 & -0.001 & 0.005 & 0.001 & 0.005 & 0.002 & 0.005 \\
\hline widow/orphan pension & -0.011 & 0.009 & -0.012 & 0.009 & -0.011 & 0.009 & -0.006 & 0.008 & 0.009 & 0.008 \\
\hline short-term unemployment benefit & 0.012 & 0.006 & 0.018 & 0.006 & 0.006 & 0.006 & 0.001 & 0.006 & -0.007 & 0.006 \\
\hline long-term unemployment benefit & 0.006 & 0.010 & 0.004 & 0.009 & -0.002 & 0.009 & -0.009 & 0.009 & -0.006 & 0.009 \\
\hline support for training/education & 0.000 & 0.011 & 0.015 & 0.010 & 0.009 & 0.010 & 0.026 & 0.010 & 0.020 & 0.010 \\
\hline maternity benefit & 0.000 & 0.010 & 0.012 & 0.010 & -0.010 & 0.010 & -0.001 & 0.010 & 0.001 & 0.010 \\
\hline student grant & 0.022 & 0.014 & 0.021 & 0.013 & 0.003 & 0.012 & -0.000 & 0.013 & 0.031 & 0.013 \\
\hline military compensation & 0.009 & 0.014 & 0.000 & 0.013 & -0.007 & 0.013 & -0.003 & 0.013 & 0.022 & 0.013 \\
\hline wage income & -0.010 & 0.005 & -0.006 & 0.005 & -0.017 & 0.004 & -0.009 & 0.004 & -0.009 & 0.005 \\
\hline income from self-employment & -0.022 & 0.006 & -0.026 & 0.006 & -0.024 & 0.006 & -0.026 & 0.006 & -0.014 & 0.006 \\
\hline income from additional employment & -0.002 & 0.006 & -0.003 & 0.006 & -0.010 & 0.006 & -0.006 & 0.006 & -0.017 & 0.006 \\
\hline payments from persons not in household & -0.010 & 0.010 & -0.003 & 0.010 & 0.014 & 0.010 & -0.014 & 0.010 & -0.002 & 0.010 \\
\hline obs & 18,122 & & 18,122 & & 18,122 & & 18,149 & & 18,147 & \\
\hline log likelihood & $-10,832$ & & $-11,993$ & & $-11,708$ & & $-12,029$ & & $-12,320$ & \\
\hline
\end{tabular}

Note: Probit regressions. Included as controls are cubic function in age, number of children and number of adults in household, and dummies for education, sex, marital status, employment status, and occupation. Income source variables are in logs. 


\section{Table 7: Regressions with future income}

\begin{tabular}{|c|c|c|c|c|c|c|c|c|c|c|}
\hline \multirow[t]{2}{*}{ Dependent variable } & \multicolumn{2}{|c|}{$\begin{array}{l}\text { Responsibility for the } \\
\text { financial security when } \\
\text { unemployed (state=1) }\end{array}$} & \multicolumn{2}{|c|}{$\begin{array}{c}\text { Responsibility for the } \\
\text { financial security when } \\
\text { sick (state }=1 \text { ) }\end{array}$} & \multicolumn{2}{|c|}{$\begin{array}{c}\text { Responsibility for the } \\
\text { financial security of the } \\
\text { family (state=1) }\end{array}$} & \multicolumn{2}{|c|}{$\begin{array}{c}\text { Responsibility for the } \\
\text { financial security when } \\
\text { old (state=1) }\end{array}$} & \multicolumn{2}{|c|}{$\begin{array}{l}\text { Responsibility for the } \\
\text { financial security when } \\
\text { requiring care } \\
(\text { state }=1)\end{array}$} \\
\hline & Coeff. & Std. Err. & Coeff. & Std. Err. & Coeff. & Std. Err. & Coeff. & Std. Err. & Coeff. & Std. Err. \\
\hline east & 0.429 & 0.036 & 0.380 & 0.034 & 0.407 & 0.034 & 0.381 & 0.034 & 0.319 & 0.034 \\
\hline future log(income) change & 0.012 & 0.041 & -0.123 & 0.040 & -0.032 & 0.040 & -0.062 & 0.040 & -0.065 & 0.040 \\
\hline obs & 7,404 & & 7,402 & & 7,399 & & 7,412 & & 7,411 & \\
\hline log likelihood & $-4,390$ & & $-4,814$ & & $-4,802$ & & $-4,895$ & & $-4,990$ & \\
\hline
\end{tabular}

Note: Probit regressions. Included as controls are cubic function in age, number of children and number of adults in household, logarithm of household income, and dummies for education, sex, marital status, employment status, and occupation.

\section{Table 8: Regressions with aggregate regional variables}

\begin{tabular}{|c|c|c|c|c|c|c|c|c|c|c|}
\hline \multirow[t]{2}{*}{ Dependent variable } & \multicolumn{2}{|c|}{$\begin{array}{l}\text { Responsibility for the } \\
\text { financial security when } \\
\text { unemployed (state=1) }\end{array}$} & \multicolumn{2}{|c|}{$\begin{array}{c}\text { Responsibility for the } \\
\text { financial security when } \\
\text { sick (state=1) }\end{array}$} & \multicolumn{2}{|c|}{$\begin{array}{l}\text { Responsibility for the } \\
\text { financial security of the } \\
\text { family (state }=1 \text { ) }\end{array}$} & \multicolumn{2}{|c|}{$\begin{array}{l}\text { Responsibility for the } \\
\text { financial security when } \\
\text { old (state=1) }\end{array}$} & \multicolumn{2}{|c|}{$\begin{array}{l}\text { Responsibility for the } \\
\text { financial security when } \\
\text { requiring care (state=1) }\end{array}$} \\
\hline & Coeff. & Std. Err. & Coeff. & Std. Err. & Coeff. & Std. Err. & Coeff. & Std. Err. & Coeff. & Std. Err. \\
\hline east & 0.293 & 0.050 & 0.330 & 0.047 & 0.367 & 0.047 & 0.313 & 0.047 & 0.235 & 0.046 \\
\hline year02 & 0.091 & 0.031 & 0.209 & 0.030 & -0.001 & 0.031 & -0.004 & 0.030 & 0.115 & 0.030 \\
\hline east ${ }^{*}$ year02 & -0.138 & 0.041 & -0.164 & 0.038 & -0.070 & 0.038 & -0.143 & 0.038 & -0.173 & 0.038 \\
\hline state income & 0.009 & 0.009 & -0.013 & 0.009 & 0.007 & 0.009 & -0.009 & 0.009 & -0.002 & 0.009 \\
\hline state unemployment & 0.014 & 0.007 & 0.007 & 0.007 & 0.008 & 0.007 & 0.004 & 0.007 & 0.003 & 0.007 \\
\hline transfers $\left({ }^{*} 10^{3}\right)$ & 0.042 & 0.022 & -0.010 & 0.021 & 0.015 & 0.021 & 0.016 & 0.021 & 0.054 & 0.021 \\
\hline obs & 18,488 & & 18,486 & & 18,484 & & 18,515 & & 18,513 & \\
\hline log likelihood & $-11,046$ & & $-12,186$ & & $-11,950$ & & $-12,244$ & & $-12,555$ & \\
\hline
\end{tabular}

Note: Probit regressions. Included as controls are cubic function in age, number of children and number of adults in household, logarithm of household income, and dummies for education, sex, marital status, employment status, and occupation. 


\section{Table 9: Regressions with residence}

\begin{tabular}{|c|c|c|c|c|c|c|c|c|c|c|}
\hline \multirow[t]{2}{*}{ Dependent variable } & \multicolumn{2}{|c|}{$\begin{array}{l}\text { Responsibility for the } \\
\text { financial security } \\
\text { when unemployed } \\
\text { (state=1) }\end{array}$} & \multicolumn{2}{|c|}{$\begin{array}{l}\text { Responsibility for the } \\
\text { financial security } \\
\text { when sick (state=1) }\end{array}$} & \multicolumn{2}{|c|}{$\begin{array}{l}\text { Responsibility for the } \\
\text { financial security of } \\
\text { the family (state=1) }\end{array}$} & \multicolumn{2}{|c|}{$\begin{array}{l}\text { Responsibility for the } \\
\text { financial security } \\
\text { when old (state=1) }\end{array}$} & \multicolumn{2}{|c|}{$\begin{array}{l}\text { Responsibility for the } \\
\text { financial security } \\
\text { when requiring care } \\
(\text { state }=1)\end{array}$} \\
\hline & Coeff. & Std. Err. & Coeff. & Std. Err. & Coeff. & Std. Err. & Coeff. & Std. Err. & Coeff. & Std. Err. \\
\hline east & 0.076 & 0.090 & 0.204 & 0.089 & 0.221 & 0.089 & 0.202 & 0.088 & 0.130 & 0.088 \\
\hline east living in East & 0.383 & 0.092 & 0.246 & 0.090 & 0.212 & 0.090 & 0.239 & 0.089 & 0.258 & 0.089 \\
\hline year02 & 0.064 & 0.023 & 0.165 & 0.023 & -0.013 & 0.024 & -0.033 & 0.023 & 0.103 & 0.023 \\
\hline east ${ }^{*}$ year02 & 0.160 & 0.117 & -0.070 & 0.111 & 0.100 & 0.114 & 0.007 & 0.107 & -0.085 & 0.113 \\
\hline (east living in East)*year02 & -0.302 & 0.119 & -0.092 & 0.113 & -0.169 & 0.114 & -0.157 & 0.108 & -0.092 & 0.114 \\
\hline obs & 18,489 & & 18,487 & & 18,485 & & 18,516 & & 18,514 & \\
\hline log likelihood & $-11,052$ & & $-12,187$ & & $-11,951$ & & $-12,246$ & & $-12,562$ & \\
\hline
\end{tabular}

Note: Probit regressions. Included as controls are cubic function in age, number of children and number of adults in household, logarithm of household income, and dummies for education, sex, marital status, employment status, and occupation.

\section{Table 10: Regressions with east states interacted with year02}

\begin{tabular}{|c|c|c|c|c|c|c|c|c|c|c|}
\hline \multirow[t]{2}{*}{ Dependent variable } & \multicolumn{2}{|c|}{$\begin{array}{c}\text { Responsibility for the } \\
\text { financial security } \\
\text { when unemployed } \\
\text { (state=1) }\end{array}$} & \multicolumn{2}{|c|}{$\begin{array}{l}\text { Responsibility for the } \\
\text { financial security } \\
\text { when sick (state=1) }\end{array}$} & \multicolumn{2}{|c|}{$\begin{array}{l}\text { Responsibility for the } \\
\text { financial security of } \\
\text { the family (state }=1 \text { ) }\end{array}$} & \multicolumn{2}{|c|}{$\begin{array}{c}\text { Responsibility for the } \\
\text { financial security } \\
\text { when old (state=1) }\end{array}$} & \multicolumn{2}{|c|}{$\begin{array}{l}\text { Responsibility for the } \\
\text { financial security } \\
\text { when requiring care } \\
\text { (state=1) }\end{array}$} \\
\hline & Coeff. & Std. Err. & Coeff. & Std. Err. & Coeff. & Std. Err. & Coeff. & Std. Err. & Coeff. & Std. Err. \\
\hline East Berlin & 0.442 & 0.091 & 0.537 & 0.083 & 0.477 & 0.082 & 0.375 & 0.082 & 0.449 & 0.083 \\
\hline Mecklenburg-Vorpommern & 0.265 & 0.068 & 0.290 & 0.064 & 0.253 & 0.064 & 0.300 & 0.063 & 0.390 & 0.064 \\
\hline Brandenburg & 0.399 & 0.062 & 0.341 & 0.057 & 0.416 & 0.057 & 0.457 & 0.057 & 0.371 & 0.057 \\
\hline Sachsen-Anhalt & 0.503 & 0.059 & 0.519 & 0.052 & 0.452 & 0.052 & 0.520 & 0.052 & 0.446 & 0.052 \\
\hline Thüringen & 0.553 & 0.060 & 0.407 & 0.053 & 0.405 & 0.052 & 0.416 & 0.052 & 0.311 & 0.052 \\
\hline Sachsen & 0.416 & 0.047 & 0.475 & 0.043 & 0.465 & 0.042 & 0.428 & 0.042 & 0.347 & 0.042 \\
\hline year02 & 0.067 & 0.023 & 0.162 & 0.023 & -0.015 & 0.024 & -0.037 & 0.023 & 0.097 & 0.023 \\
\hline East Berlin * year02 & -0.048 & 0.127 & -0.376 & 0.107 & 0.020 & 0.109 & -0.026 & 0.109 & -0.137 & 0.110 \\
\hline Mecklenburg-Vorpommern * year02 & 0.086 & 0.099 & -0.005 & 0.092 & 0.066 & 0.089 & 0.010 & 0.088 & -0.178 & 0.090 \\
\hline Brandenburg * year02 & -0.023 & 0.085 & -0.029 & 0.075 & 0.025 & 0.072 & -0.134 & 0.075 & -0.229 & 0.075 \\
\hline Sachsen-Anhalt * year02 & -0.130 & 0.079 & -0.226 & 0.069 & -0.110 & 0.071 & -0.213 & 0.068 & -0.220 & 0.070 \\
\hline Thüringen * year02 & -0.457 & 0.075 & -0.138 & 0.070 & -0.096 & 0.068 & -0.123 & 0.070 & -0.010 & 0.067 \\
\hline Sachsen * year02 & -0.063 & 0.061 & -0.200 & 0.056 & -0.106 & 0.055 & -0.185 & 0.054 & -0.207 & 0.056 \\
\hline obs & 18,286 & & 18,283 & & 18,283 & & 18,312 & & 18,311 & \\
\hline log likelihood & $-10,919$ & & $-12,042$ & & $-11,812$ & & $-12,098$ & & $-12,414$ & \\
\hline
\end{tabular}

Note: Probit regressions. Included as controls are cubic function in age, number of children and number of adults in household, logarithm of household income, and dummies for education, sex, marital status, employment status, and occupation. 
Table 11: Regressions with social conditions as the dependent variable

\begin{tabular}{|c|c|c|c|c|}
\hline \multirow{2}{*}{$\begin{array}{l}\text { Dependent variable: } \\
\text { Social conditions define possibilities } \\
(\text { agree }=1)\end{array}$} & \multicolumn{2}{|c|}{ BASIC REGRESSION } & \multicolumn{2}{|c|}{$\begin{array}{l}\text { REGRESSION INCLUDING } \\
\text { AGE*EAST INTERACTION }\end{array}$} \\
\hline & Coeff. & Std. Err. & Coeff. & Std. Err. \\
\hline east & 0.292 & 0.032 & -0.186 & 0.085 \\
\hline age*east & & & 0.011 & 0.002 \\
\hline age & 0.008 & 0.022 & 0.002 & 0.002 \\
\hline age squared & -0.000 & 0.000 & & \\
\hline age cubed & -0.000 & 0.000 & & \\
\hline college & -0.097 & 0.097 & -0.116 & 0.093 \\
\hline vocational training & -0.073 & 0.089 & -0.077 & 0.085 \\
\hline secondary schooling & -0.030 & 0.091 & -0.024 & 0.089 \\
\hline intermediate schooling & -0.033 & 0.104 & -0.038 & 0.103 \\
\hline male & -0.145 & 0.031 & -0.145 & 0.031 \\
\hline number of children & 0.018 & 0.017 & 0.022 & 0.017 \\
\hline number of adults & 0.047 & 0.015 & 0.048 & 0.015 \\
\hline married & -0.035 & 0.051 & -0.039 & 0.047 \\
\hline divorced & 0.037 & 0.072 & 0.036 & 0.069 \\
\hline married but separated & 0.009 & 0.125 & 0.014 & 0.124 \\
\hline widowed & 0.127 & 0.084 & 0.128 & 0.083 \\
\hline $\log$ (household income) & -0.140 & 0.037 & -0.135 & 0.037 \\
\hline civil servant & -0.181 & 0.076 & -0.178 & 0.076 \\
\hline self-employed & -0.266 & 0.070 & -0.267 & 0.069 \\
\hline white-collar worker & -0.027 & 0.044 & -0.032 & 0.044 \\
\hline unemployed & 0.159 & 0.068 & 0.152 & 0.068 \\
\hline retired & -0.121 & 0.086 & -0.126 & 0.073 \\
\hline maternity & 0.028 & 0.112 & 0.018 & 0.112 \\
\hline nonworking & 0064 & 0.059 & 0.051 & 0.059 \\
\hline training & 0.049 & 0.095 & 0.049 & 0.093 \\
\hline other nonworking & -0.161 & 0.071 & -0.169 & 0.070 \\
\hline constant & 1.201 & 0.439 & 1.390 & 0.322 \\
\hline obs & 8,580 & & 8,580 & \\
\hline log likelihood & $-5,412$ & & $-5,394$ & \\
\hline
\end{tabular}

Note: Probit regressions. Omitted categories are less than 9 years of schooling, female, single, blue-collar worker, and employed.

Table 12: Regressions with social conditions as a control variable

\begin{tabular}{|l|cc|cc|cc|c|c|}
\hline Dependent variable & $\begin{array}{c}\text { Responsibility for the } \\
\text { financial security } \\
\text { when unemployed } \\
\text { (state=1) }\end{array}$ & $\begin{array}{c}\text { Responsibility for the } \\
\text { financial security when } \\
\text { sick (state=1) }\end{array}$ & $\begin{array}{c}\text { Responsibility for the } \\
\text { financial security of the } \\
\text { family (state=1) }\end{array}$ & $\begin{array}{c}\text { Responsibility for the } \\
\text { financial security when } \\
\text { old (state=1) }\end{array}$ & $\begin{array}{c}\text { Responsibility for the } \\
\text { financial security when } \\
\text { requiring care (state=1) }\end{array}$ \\
\hline \hline east & Std. Err. & Coeff. & Std. Err. & Coeff. & Std. Err. & Coeff. & Std. Err. & Coeff. \\
Std. Err.
\end{tabular}

Note: Probit regressions. Included as controls are cubic function in age, number of children and number of adults in household, logarithm of household income, and dummies for education, sex, marital status, employment status, and occupation. 
Table 13: Regressions with luck as the dependent variable

\begin{tabular}{|c|c|c|c|c|}
\hline \multirow[t]{2}{*}{$\begin{array}{l}\text { Dependent variable: } \\
\text { Life achievements determined by luck (agree=1) }\end{array}$} & \multicolumn{2}{|c|}{ BASIC REGRESSION } & \multicolumn{2}{|c|}{$\begin{array}{l}\text { REGRESSION INCLUDING } \\
\text { AGE*EAST INTERACTION }\end{array}$} \\
\hline & Coeff. & Std. Err. & Coeff. & Std. Err. \\
\hline east & -0.273 & 0.031 & -0.402 & 0.081 \\
\hline age*east & & & 0.003 & 0.002 \\
\hline age & -0.109 & 0.020 & 0.011 & 0.002 \\
\hline age squared & 0.002 & 0.000 & & \\
\hline age cubed & -0.000 & 0.000 & & \\
\hline college & -0.864 & 0.094 & -1.009 & 0.091 \\
\hline vocational training & -0.223 & 0.084 & -0.359 & 0.080 \\
\hline secondary schooling & -0.134 & 0.086 & -0.230 & 0.084 \\
\hline intermediate schooling & -0.186 & 0.097 & -0.227 & 0.097 \\
\hline male & -0.149 & 0.030 & -0.143 & 0.030 \\
\hline number of children & 0.032 & 0.016 & 0.015 & 0.016 \\
\hline number of adults & 0.068 & 0.014 & 0.074 & 0.014 \\
\hline married & 0.037 & 0.050 & -0.045 & 0.046 \\
\hline divorced & 0.075 & 0.069 & -0.016 & 0.066 \\
\hline married but separated & 0.182 & 0.117 & 0.103 & 0.115 \\
\hline widowed & 0.195 & 0.078 & 0.103 & 0.076 \\
\hline $\log$ (household income) & -0.406 & 0.036 & -0.403 & 0.036 \\
\hline civil servant & -0.357 & 0.085 & -0.374 & 0.085 \\
\hline self-employed & -0.145 & 0.070 & -0.166 & 0.070 \\
\hline white-collar worker & -0.173 & 0.043 & -0.197 & 0.043 \\
\hline unemployed & -0.015 & 0.062 & -0.019 & 0.062 \\
\hline retired & -0.079 & 0.080 & -0.035 & 0.068 \\
\hline maternity & -0.287 & 0.112 & -0.278 & 0.112 \\
\hline nonworking & -0.056 & 0.055 & -0.016 & 0.054 \\
\hline training & -0.370 & 0.092 & -0.263 & 0.090 \\
\hline other nonworking & -0.374 & 0.070 & -0.314 & 0.069 \\
\hline constant & 4.586 & 0.419 & 2.972 & 0.311 \\
\hline obs & 9,753 & & 9,753 & \\
\hline log likelihood & $-5,700$ & & $-5,717$ & \\
\hline
\end{tabular}

Note: Probit regressions. Omitted categories are less than 9 years of schooling, female, single, blue-collar worker, and employed.

\section{Table 14: Regressions with luck as a control variable}

\begin{tabular}{|c|c|c|c|c|c|c|c|c|c|c|}
\hline \multirow[t]{2}{*}{ Dependent variable } & \multicolumn{2}{|c|}{$\begin{array}{l}\text { Responsibility for the } \\
\text { financial security when } \\
\text { unemployed (state }=1 \text { ) }\end{array}$} & \multicolumn{2}{|c|}{$\begin{array}{c}\text { Responsibility for the } \\
\text { financial security when } \\
\text { sick (state=1) }\end{array}$} & \multicolumn{2}{|c|}{$\begin{array}{l}\text { Responsibility for the } \\
\text { financial security of the } \\
\text { family (state }=1 \text { ) }\end{array}$} & \multicolumn{2}{|c|}{$\begin{array}{c}\text { Responsibility for the } \\
\text { financial security when } \\
\text { old (state }=1 \text { ) }\end{array}$} & \multicolumn{2}{|c|}{$\begin{array}{l}\text { Responsibility for the } \\
\text { financial security when } \\
\text { requiring care (state }=1 \text { ) }\end{array}$} \\
\hline & Coeff. & Std. Err. & Coeff. & Std. Err. & Coeff. & Std. Err. & Coeff. & Std. Err. & Coeff. & Std. Err. \\
\hline east & 0.432 & 0.030 & 0.442 & 0.029 & 0.430 & 0.028 & 0.435 & 0.028 & 0.375 & 0.028 \\
\hline year02 & 0.061 & 0.023 & 0.160 & 0.024 & -0.022 & 0.025 & -0.039 & 0.024 & 0.102 & 0.023 \\
\hline east ${ }^{*}$ year02 & -0.134 & 0.040 & -0.142 & 0.037 & -0.046 & 0.037 & -0.119 & 0.037 & -0.157 & 0.037 \\
\hline luck & 0.038 & 0.024 & 0.135 & 0.023 & 0.077 & 0.023 & 0.114 & 0.023 & 0.067 & 0.023 \\
\hline obs & 17,532 & & 17,535 & & 17,530 & & 17,559 & & 17,558 & \\
\hline log likelihood & -10.510 & & $-11,540$ & & $-11,331$ & & $-11,600$ & & $-11,906$ & \\
\hline
\end{tabular}

Note: Probit regressions. Included as controls are cubic function in age, number of children and number of adults in household, logarithm of household income, and dummies for education, sex, marital status, employment status, and occupation. 
Figure 1: By how many percentage points is an East German of a certain birth cohort group more likely to favor state intervention than a West German of the same birth cohort group?

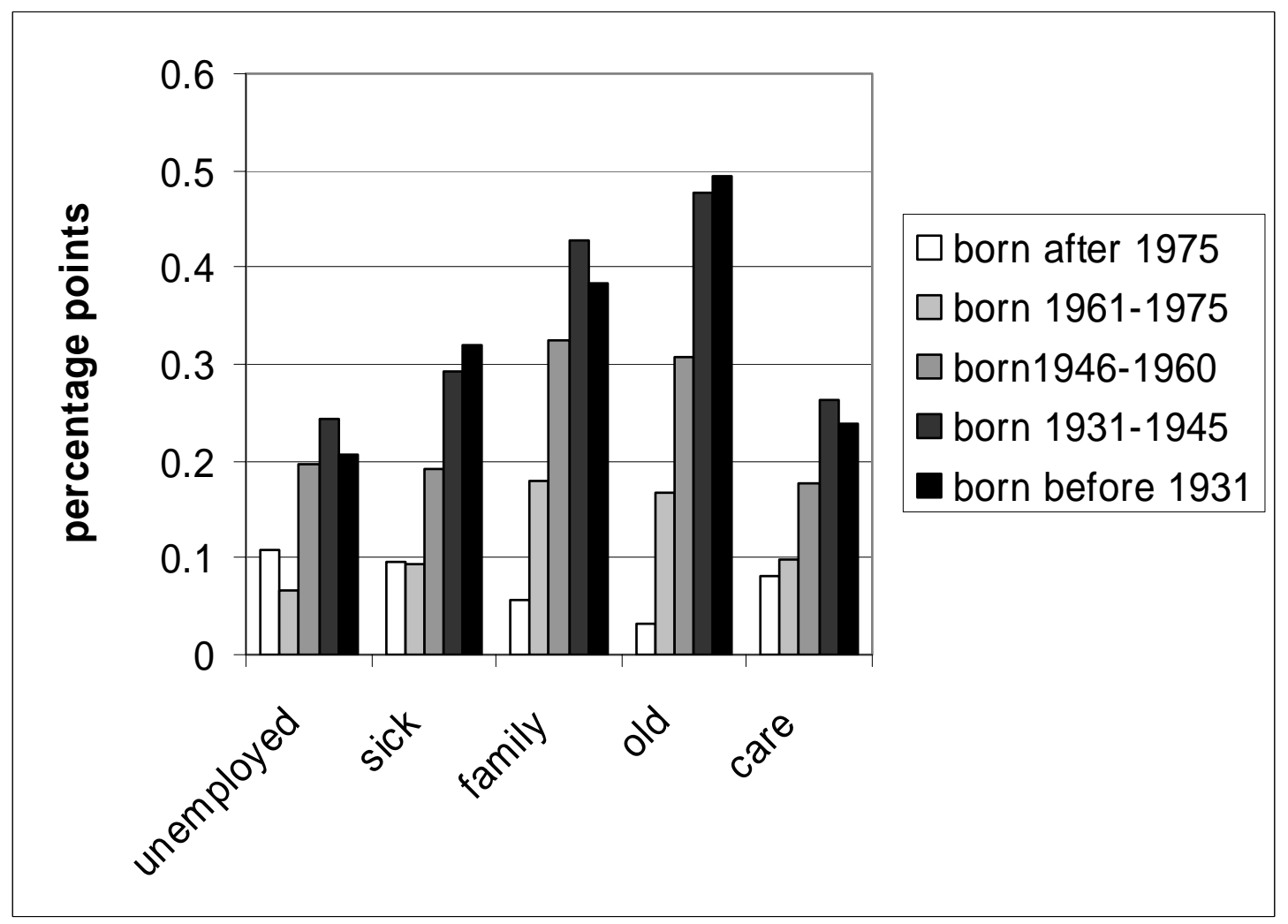


Table A1: Average per capita income 1928, 1932, and 1936 by region

\begin{tabular}{|c|c|c|c|}
\hline & $\begin{array}{c}1928 \\
\text { (in } 1928 \text { Mark) }\end{array}$ & $\begin{array}{c}1932 \\
\text { (in } 1928 \text { Mark) }\end{array}$ & $\begin{array}{c}1936 \\
\text { (in } 1928 \text { Mark) }\end{array}$ \\
\hline Prussia & 1,174 & 869 & 1,161 \\
\hline Provinz East-Prussia & 814 & 673 & 849 \\
\hline Stadt Berlin (E/W) & 1,822 & 1311 & 1,895 \\
\hline Provinz Brandenburg (E) & 1,140 & 917 & 1,158 \\
\hline Provinz Pommern & 921 & 721 & 967 \\
\hline Grenzmark Posen/West-Prussia & 837 & 649 & 781 \\
\hline Niederschlesien & 1,057 & 804 & 953 \\
\hline Oberschlesien & 850 & 599 & 758 \\
\hline Sachsen (E) & 1,155 & 844 & 1,161 \\
\hline Schleswig-Holstein (W) & 1,164 & 938 & 1,192 \\
\hline Hannover (W) & 1,069 & 859 & 1,156 \\
\hline Westfalen (W) & 1,080 & 755 & 1,045 \\
\hline Hessen-Nassau (W) & 1,226 & 963 & 1,140 \\
\hline Rheinprovinz (W) & 1,218 & 857 & 1,171 \\
\hline Bayern (W) & 1,041 & 785 & 1,049 \\
\hline Sachsen (E) & 1,423 & 964 & 1,270 \\
\hline Württemberg (W) & 1,183 & 1015 & 1,348 \\
\hline Baden (W) & 1,135 & 859 & 1,117 \\
\hline Thüringen (E) & 1,095 & 784 & 1,087 \\
\hline Hessen (W) & 1,158 & 797 & 1,039 \\
\hline Hamburg (W) & 1,754 & 1304 & 1,746 \\
\hline Other Länder & 1,155 & 913 & 1,314 \\
\hline Deutsches Reich & 1,185 & 875 & 1,173 \\
\hline
\end{tabular}

Source: Statistisches Jahrbuch für das Deutsche Reich, various issues. 
Table A2: Summary statistics

\begin{tabular}{|c|c|c|c|c|c|}
\hline \multirow[t]{2}{*}{ year } & \multirow[t]{2}{*}{ variable } & \multicolumn{2}{|c|}{ West sample } & \multicolumn{2}{|c|}{ East Sample } \\
\hline & & Obs. & Per cent & Obs. & Per cent \\
\hline \multirow[t]{5}{*}{1997} & $\begin{array}{l}\text { Responsibility for the financial } \\
\text { security when unemployed } \\
\text { (state=1) }\end{array}$ & 6,104 & $63.24 \%$ & 3,735 & $78.85 \%$ \\
\hline & $\begin{array}{l}\text { Responsibility for the financial } \\
\text { security when sick (state=1) }\end{array}$ & 6,105 & $34.50 \%$ & 3,728 & $52.76 \%$ \\
\hline & $\begin{array}{l}\text { Responsibility for the financial } \\
\text { security of the family (state }=1 \text { ) }\end{array}$ & 6,095 & $32.78 \%$ & 3,732 & $49.06 \%$ \\
\hline & $\begin{array}{l}\text { Responsibility for the financial } \\
\text { security when old (state }=1 \text { ) }\end{array}$ & 6,110 & $38.46 \%$ & 3,737 & $56.09 \%$ \\
\hline & $\begin{array}{l}\text { Responsibility for the financial } \\
\text { security when requiring care } \\
\text { (state=1) }\end{array}$ & 6,110 & $40.77 \%$ & 3,737 & $56.44 \%$ \\
\hline \multirow[t]{5}{*}{2002} & $\begin{array}{l}\text { Responsibility for the financial } \\
\text { security when unemployed } \\
(\text { state=1) }\end{array}$ & 5,307 & $65.33 \%$ & 3,343 & $76.64 \%$ \\
\hline & $\begin{array}{l}\text { Responsibility for the financial } \\
\text { security when sick (state=1) }\end{array}$ & 5,309 & $40.01 \%$ & 3,345 & $51.81 \%$ \\
\hline & $\begin{array}{l}\text { Responsibility for the financial } \\
\text { security of the family (state }=1 \text { ) }\end{array}$ & 5,311 & $32.10 \%$ & 3,347 & $45.65 \%$ \\
\hline & $\begin{array}{l}\text { Responsibility for the financial } \\
\text { security when old (state }=1 \text { ) }\end{array}$ & 5,319 & $36.70 \%$ & 3,350 & $48.51 \%$ \\
\hline & $\begin{array}{l}\text { Responsibility for the financial } \\
\text { security when requiring care } \\
\text { (state=1) }\end{array}$ & 5,313 & $44.27 \%$ & 3,354 & $53.04 \%$ \\
\hline
\end{tabular}

\begin{tabular}{|c|c|c|c|c|c|}
\hline \hline year & \multicolumn{1}{|c|}{ variable } & \multicolumn{2}{|c|}{ West sample } & \multicolumn{2}{c|}{ East Sample } \\
\cline { 3 - 5 } & & Obs. & Per cent & Obs. & Per cent \\
\hline \hline 1997 & $\begin{array}{l}\text { Life achievements determined } \\
\text { by luck or effort (luck=1) }\end{array}$ & 6,555 & $40.23 \%$ & 4,070 & $31.40 \%$ \\
$\begin{array}{l}\text { Social conditions define } \\
\text { possibilities (agree=1) }\end{array}$ & 5,523 & $60.44 \%$ & 3,465 & $72.41 \%$ \\
\hline \hline
\end{tabular}


Table A3: Summary statistics for the independent variables

\begin{tabular}{|c|c|c|c|c|c|}
\hline \multirow[t]{2}{*}{ year } & \multirow[t]{2}{*}{ variable } & \multicolumn{2}{|c|}{ West sample } & \multicolumn{2}{|c|}{ East Sample } \\
\hline & & Mean & Std. Dev. & Mean & Std. Dev. \\
\hline \multirow[t]{22}{*}{1997} & age & 43.7 & 18.5 & 41.3 & 18.2 \\
\hline & college & $10.4 \%$ & & $19.5 \%$ & \\
\hline & vocational training & $52.9 \%$ & & $51.5 \%$ & \\
\hline & secondary schooling & $15.7 \%$ & & $7.6 \%$ & \\
\hline & intermediate schooling & $17.6 \%$ & & $17.7 \%$ & \\
\hline & male & $47.9 \%$ & & $48.4 \%$ & \\
\hline & number of children & 0.823 & 1.040 & 0.712 & 0.903 \\
\hline & number of adults & 2.411 & 1.107 & 2.521 & 1.121 \\
\hline & married & $60.8 \%$ & & $61.9 \%$ & \\
\hline & divorced & $6.5 \%$ & & $6.6 \%$ & \\
\hline & married but separated & $1.6 \%$ & & $1.2 \%$ & \\
\hline & widowed & $7.6 \%$ & & $6.2 \%$ & \\
\hline & household income & 4,914 & 2,431 & 4,069 & 1,897 \\
\hline & civil servant & $4.8 \%$ & & $1.6 \%$ & \\
\hline & self-employed & $4.8 \%$ & & $3.8 \%$ & \\
\hline & white-collar worker & $24.7 \%$ & & $22.4 \%$ & \\
\hline & unemployed & $3.6 \%$ & & $10.5 \%$ & \\
\hline & retired & $15.9 \%$ & & $11.9 \%$ & \\
\hline & maternity & $1.8 \%$ & & $1.6 \%$ & \\
\hline & nonworking & $12.7 \%$ & & $9.4 \%$ & \\
\hline & training & $3.1 \%$ & & $4.0 \%$ & \\
\hline & other nonworking & $5.2 \%$ & & $4.9 \%$ & \\
\hline \multirow[t]{22}{*}{2002} & age & 46.9 & 17.8 & 44.5 & 17.3 \\
\hline & college & $11.5 \%$ & & $20.6 \%$ & \\
\hline & vocational training & $52.8 \%$ & & $54.5 \%$ & \\
\hline & secondary schooling & $15.2 \%$ & & $7.1 \%$ & \\
\hline & intermediate schooling & $15.2 \%$ & & $13.4 \%$ & \\
\hline & male & $47.7 \%$ & & $48.8 \%$ & \\
\hline & number of children & 0.788 & 0.988 & 0.576 & 0.818 \\
\hline & number of adults & 2.193 & 0.939 & 2.286 & 0.898 \\
\hline & married & $61.3 \%$ & & $56.7 \%$ & \\
\hline & divorced & $6.8 \%$ & & $7.5 \%$ & \\
\hline & married but separated & $1.5 \%$ & & $1.9 \%$ & \\
\hline & widowed & $7.4 \%$ & & $6.4 \%$ & \\
\hline & household income & 5,179 & 2,813 & 4,258 & 2,011 \\
\hline & civil servant & $4.2 \%$ & & $1.8 \%$ & \\
\hline & self-employed & $5.4 \%$ & & $3.8 \%$ & \\
\hline & white-collar worker & $27.8 \%$ & & $23.6 \%$ & \\
\hline & unemployed & $2.9 \%$ & & $9.0 \%$ & \\
\hline & retired & $18.3 \%$ & & $14.9 \%$ & \\
\hline & maternity & $2.2 \%$ & & $1.8 \%$ & \\
\hline & nonworking & $10.6 \%$ & & $8.3 \%$ & \\
\hline & training & $3.0 \%$ & & $4.2 \%$ & \\
\hline & other nonworking & $5.0 \%$ & & $5.9 \%$ & \\
\hline
\end{tabular}

Note: Omitted categories are less than 9 years of schooling, female, single, blue-collar worker, and employed. 
Table A4: Average income per capita, unemployment rates, and transfers by states

\begin{tabular}{lcccccc}
\hline \hline & \multicolumn{2}{c}{$\begin{array}{c}\text { Average income per } \\
\text { capita (in DM) }\end{array}$} & $\begin{array}{c}\text { Unemployment } \\
\text { rates (in \%) }\end{array}$ & $\begin{array}{c}\text { Transfers per capita } \\
\text { (in DM) }\end{array}$ \\
& $1997^{*}$ & 2002 & 1997 & 2002 & $1997^{*}$ & 2002 \\
\hline Berlin & 28,830 & 28,528 & 17.3 & 16.9 & 2,922 & 3,020 \\
WEST & & & & & & \\
Baden-Württemberg & 32,621 & 34,843 & 8.7 & 5.4 & -249 & -305 \\
Bayern & 32,011 & 33,895 & 8.7 & 6.0 & -276 & -325 \\
Bremen & 35,588 & 37,231 & 16.8 & 12.6 & 3,912 & 3,458 \\
Hamburg & 35,056 & 36,709 & 13.0 & 9.0 & -172 & -223 \\
Hessen & 30,683 & 32,803 & 10.4 & 6.9 & -559 & -614 \\
Niedersachsen & 30,149 & 31,473 & 12.9 & 9.2 & 285 & 319 \\
Nordrhein-Westfalen & 32,198 & 34,168 & 12.2 & 9.2 & -182 & -176 \\
Rheinland-Pfalz, Saarland & 29,625 & 31,329 & 11.0 & 7.6 & 720 & 649 \\
Schleswig-Holstein & 31,178 & 31,655 & 11.2 & 8.7 & 132 & 278 \\
EAST & & & & & 1,2 & \\
Brandenburg & 26,288 & 28,047 & 18.9 & 17.5 & 1,889 & 1,793 \\
Mecklenburg-Vorpommern & 24,878 & 26,834 & 20.3 & 18.6 & 2,067 & 2,016 \\
Sachsen & 25,867 & 28,099 & 18.4 & 17.8 & 1,912 & 1,893 \\
Sachsen-Anhalt & 25,227 & 27,313 & 21.7 & 19.6 & 1,998 & 1,985 \\
Thüringen & 25,338 & 27,941 & 19.1 & 15.9 & 2,015 & 1,954 \\
\hline
\end{tabular}

* Values adjusted for inflation. 
Table A5: Basic regression - ordered probit

\begin{tabular}{|c|c|c|c|c|c|c|c|c|c|c|}
\hline \multirow[t]{2}{*}{ Dependent variable } & \multicolumn{2}{|c|}{$\begin{array}{c}\text { Responsibility for the } \\
\text { financial security when } \\
\text { unemployed (state }=1 \text {, } \\
\text { private }=5)\end{array}$} & \multicolumn{2}{|c|}{$\begin{array}{c}\text { Responsibility for the } \\
\text { financial security when } \\
\text { sick (state=1, } \\
\text { private }=5 \text { ) }\end{array}$} & \multicolumn{2}{|c|}{$\begin{array}{c}\text { Responsibility for the } \\
\text { financial security of } \\
\text { the family (state }=1, \\
\text { private }=5 \text { ) }\end{array}$} & \multicolumn{2}{|c|}{$\begin{array}{c}\text { Responsibility for the } \\
\text { financial security when } \\
\text { old (state=1, } \\
\text { private }=5)\end{array}$} & \multicolumn{2}{|c|}{$\begin{array}{l}\text { Responsibility for the } \\
\text { financial security when } \\
\text { requiring care } \\
\text { (state }=1 \text {, private }=5 \text { ) }\end{array}$} \\
\hline & Coeff. & Std. Err. & Coeff. & Std. Err. & Coeff. & Std. Err. & Coeff. & Std. Err. & Coeff. & Std. Err. \\
\hline east & -0.378 & 0.024 & -0.376 & 0.024 & -0.349 & 0.024 & -0.342 & 0.024 & -0.307 & 0.024 \\
\hline year02 & -0.038 & 0.019 & -0.151 & 0.020 & -0.014 & 0.020 & 0.001 & 0.019 & -0.090 & 0.020 \\
\hline east ${ }^{*}$ year02 & 0.102 & 0.030 & 0.137 & 0.030 & 0.031 & 0.029 & 0.122 & 0.030 & 0.157 & 0.031 \\
\hline age & 0.016 & 0.013 & -0.002 & 0.013 & 0.004 & 0.013 & 0.006 & 0.013 & 0.007 & 0.013 \\
\hline age squared $\left({ }^{*} 10^{3}\right)$ & -0.367 & 0.253 & -0.030 & 0.261 & -0.133 & 0.258 & -0.195 & 0.251 & -0.063 & 0.259 \\
\hline age cubed $\left({ }^{*} 10^{3}\right)$ & 0.002 & 0.002 & 0.000 & 0.002 & 0.001 & 0.002 & 0.001 & 0.002 & -0.000 & 0.002 \\
\hline college & 0.278 & 0.055 & 0.339 & 0.056 & 0.200 & 0.056 & 0.294 & 0.057 & 0.240 & 0.055 \\
\hline vocational training & 0.193 & 0.050 & 0.213 & 0.050 & 0.176 & 0.051 & 0.195 & 0.051 & 0.183 & 0.050 \\
\hline secondary schooling & 0.183 & 0.051 & 0.160 & 0.052 & 0.076 & 0.052 & 0.175 & 0.053 & 0.167 & 0.052 \\
\hline intermediate schooling & 0.171 & 0.058 & 0.146 & 0.059 & 0.155 & 0.059 & 0.131 & 0.060 & 0.144 & 0.060 \\
\hline male & 0.057 & 0.019 & 0.098 & 0.019 & 0.022 & 0.018 & 0.072 & 0.019 & 0.022 & 0.019 \\
\hline number of children & -0.018 & 0.011 & -0.027 & 0.010 & -0.045 & 0.010 & -0.027 & 0.010 & -0.008 & 0.010 \\
\hline number of adults & -0.016 & 0.010 & -0.047 & 0.010 & -0.029 & 0.010 & -0.038 & 0.009 & -0.008 & 0.010 \\
\hline married & -0.036 & 0.031 & -0.061 & 0.032 & -0.006 & 0.031 & -0.012 & 0.031 & -0.084 & 0.032 \\
\hline divorced & -0.084 & 0.043 & -0.003 & 0.044 & -0.055 & 0.043 & -0.030 & 0.044 & -0.083 & 0.045 \\
\hline married but separated & 0.065 & 0.067 & 0.026 & 0.068 & 0.034 & 0.066 & -0.055 & 0.069 & -0.139 & 0.069 \\
\hline widowed & 0.009 & 0.050 & -0.032 & 0.049 & 0.018 & 0.049 & 0.047 & 0.048 & -0.051 & 0.050 \\
\hline $\log$ (household income) & 0.129 & 0.022 & 0.234 & 0.022 & 0.135 & 0.021 & 0.217 & 0.022 & 0.144 & 0.022 \\
\hline civil servant & 0.114 & 0.048 & 0.203 & 0.049 & -0.093 & 0.049 & 0.121 & 0.047 & 0.105 & 0.046 \\
\hline self-employed & 0.302 & 0.044 & 0.381 & 0.044 & 0.317 & 0.044 & 0.441 & 0.043 & 0.319 & 0.043 \\
\hline white-collar worker & 0.056 & 0.027 & 0.062 & 0.027 & 0.012 & 0.026 & 0.130 & 0.027 & 0.123 & 0.027 \\
\hline unemployed & -0.113 & 0.037 & -0.009 & 0.039 & -0.119 & 0.037 & 0.008 & 0.039 & 0.024 & 0.040 \\
\hline retired & 0.027 & 0.047 & 0.090 & 0.050 & -0.098 & 0.048 & 0.085 & 0.048 & 0.040 & 0.049 \\
\hline maternity & -0.034 & 0.061 & 0.030 & 0.062 & -0.099 & 0.056 & 0.162 & 0.060 & 0.116 & 0.062 \\
\hline nonworking & -0.009 & 0.034 & 0.018 & 0.035 & -0.147 & 0.034 & 0.026 & 0.034 & 0.000 & 0.035 \\
\hline training & 0.018 & 0.054 & 0.008 & 0.056 & 0.059 & 0.056 & -0.002 & 0.054 & 0.022 & 0.056 \\
\hline other nonworking & 0.008 & 0.041 & 0.186 & 0.042 & -0.048 & 0.043 & 0.058 & 0.043 & 0.088 & 0.043 \\
\hline obs & 18,688 & & 18,688 & & 18,688 & & 18,688 & & 18,688 & \\
\hline log likelihood & $-22,278$ & & $-21,857$ & & $-23,366$ & & $-22,695$ & & $-21,306$ & \\
\hline
\end{tabular}

Note: Ordered probit regressions. Omitted categories are less than 9 years of schooling, female, single, blue-collar worker, and employed. 
Table A6: Results of elections for the Bundestag, 1998 and 2002

\begin{tabular}{|c|c|c|c|c|c|c|c|}
\hline State & year & PDS & GRÜNE & SPD & CDU/CSU & FDP & others \\
\hline \multicolumn{8}{|l|}{ Berlin } \\
\hline & 1998 & 13.4 & 11.3 & 37.8 & 23.7 & 4.9 & 8.8 \\
\hline & 2002 & 11.4 & 14.6 & 36.6 & 25.9 & 6.6 & 4.9 \\
\hline \multicolumn{8}{|c|}{ WEST } \\
\hline \multicolumn{8}{|c|}{ Baden-Württemberg } \\
\hline & 1998 & 1.0 & 9.2 & 35.6 & 37.8 & 8.8 & 7.6 \\
\hline & 2002 & 0.9 & 11.4 & 33.5 & 42.8 & 7.8 & 3.6 \\
\hline \multicolumn{8}{|c|}{ Bayern } \\
\hline & 1998 & 0.7 & 5.9 & 34.4 & 47.7 & 5.1 & 6.2 \\
\hline & 2002 & 0.7 & 7.6 & 26.1 & 58.6 & 4.5 & 2.4 \\
\hline \multicolumn{8}{|c|}{ Bremen } \\
\hline & 1998 & 2.4 & 11.3 & 50.2 & 25.4 & 5.9 & 4.7 \\
\hline & 2002 & 2.2 & 15.0 & 48.6 & 24.6 & 6.7 & 2.9 \\
\hline \multicolumn{8}{|c|}{ Hamburg } \\
\hline & 1998 & 2.3 & 10.8 & 45.7 & 30.0 & 6.5 & 4.7 \\
\hline & 2002 & 2.1 & 16.2 & 42.0 & 28.1 & 6.8 & 4.8 \\
\hline \multicolumn{8}{|c|}{ Hessen } \\
\hline & 1998 & 1.5 & 8.2 & 41.6 & 34.7 & 7.9 & 6.2 \\
\hline & 2002 & 1.3 & 10.7 & 39.7 & 37.1 & 8.2 & 2.9 \\
\hline \multicolumn{8}{|c|}{ Niedersachsen } \\
\hline & 1998 & 1.0 & 5.9 & 49.4 & 34.1 & 6.4 & 3.2 \\
\hline & 2002 & 1.0 & 7.3 & 47.8 & 34.5 & 7.1 & 2.2 \\
\hline \multicolumn{8}{|c|}{ Nordrhein-Westfalen } \\
\hline & 1998 & 1.2 & 6.9 & 46.9 & 33.8 & 7.3 & 4.0 \\
\hline & 2002 & 1.2 & 8.9 & 43.0 & 35.1 & 9.3 & 2.5 \\
\hline \multicolumn{8}{|c|}{ Rheinland-Pfalz } \\
\hline & 1998 & 1.0 & 6.1 & 41.3 & 39.1 & 7.1 & 5.4 \\
\hline & 2002 & 1.0 & 7.9 & 38.2 & 40.2 & 9.3 & 3.3 \\
\hline \multicolumn{8}{|c|}{ Saarland } \\
\hline & 1998 & 1.0 & 5.5 & 52.4 & 31.8 & 4.7 & 4.5 \\
\hline & 2002 & 1.4 & 7.6 & 46.0 & 35.0 & 6.4 & 3.7 \\
\hline \multicolumn{8}{|c|}{ Schleswig-Holstein } \\
\hline & 1998 & 1.5 & 6.5 & 45.4 & 35.7 & 7.6 & 3.3 \\
\hline & 2002 & 1.3 & 9.4 & 42.9 & 36.0 & 8.0 & 2.4 \\
\hline \multicolumn{8}{|l|}{ EAST } \\
\hline \multicolumn{8}{|c|}{ Brandenburg } \\
\hline & 1998 & 20.3 & 3.6 & 43.5 & 20.8 & 2.8 & 8.9 \\
\hline & 2002 & 17.2 & 4.5 & 46.4 & 22.3 & 5.8 & 3.8 \\
\hline \multicolumn{8}{|c|}{ Mecklenburg-Vorpommern } \\
\hline & 1998 & 23.6 & 2.9 & 35.3 & 29.3 & 2.2 & 6.6 \\
\hline & 2002 & 16.3 & 3.5 & 41.7 & 30.3 & 5.4 & 2.8 \\
\hline \multicolumn{8}{|c|}{ Sachsen } \\
\hline & 1998 & 20.0 & 4.4 & 29.1 & 32.7 & 3.6 & 10.2 \\
\hline & 2002 & 16.2 & 4.6 & 33.3 & 33.6 & 7.3 & 5.1 \\
\hline \multicolumn{8}{|c|}{ Sachsen-Anhalt } \\
\hline & 1998 & 20.7 & 3.3 & 38.1 & 27.2 & 4.1 & 6.6 \\
\hline & 2002 & 14.4 & 3.4 & 43.2 & 29.0 & 7.6 & 2.4 \\
\hline \multicolumn{8}{|c|}{ Thüringen } \\
\hline & 1998 & 21.2 & 3.9 & 34.5 & 28.9 & 3.4 & 8.1 \\
\hline & 2002 & 17.0 & 4.3 & 39.9 & 29.4 & 5.9 & 3.6 \\
\hline
\end{tabular}

Source: Statistisches Bundesamt, Wirtschaft und Statistik 10/2002, p.827, Table 4. 